\title{
Wealth effects of farmout arrangements in the oil and gas industry
}

\author{
Luiz Fernando Distadio^ \\ Andrew Ferguson ${ }^{\# *}$ \\ Peter Lam ${ }^{\#}$ \\ ${ }^{\wedge}$ Griffith University \\ \#University of Technology Sydney
}

August 2019

*Corresponding author's email: Andrew.Ferguson@uts.edu.au

We wish to thank seminar participants at the UTS Summer Symposium and at the AFAANZ 2019 conference, Brisbane for comments and suggestions. 


\begin{abstract}
We examine market reactions to farmout agreements, a popular form of strategic alliance, undertaken by oil and gas firms worldwide. This study is motivated by a gap in the literature regarding empirical studies of farmout arrangements. Using a sample of 589 farmor and 389 farminee announcements over 722 farmout agreements during the period 1990-2016, we document significant market reactions in order of $3.6 \%$ over a three-day event window to the farmors. Cross-sectional regressions of event returns provide results consistent with the resource pooling and expertise hypotheses. Furthermore, we also find evidence consistent with farmout agreements as real options by showing that farmors' stock prices are sensitive to the underlying oil price uncertainty.
\end{abstract}

Keywords; Alliances, farmout, oil and gas, resource pooling, real options

JEL classification: G30, G34, D22, D23, D24, L24 


\section{Introduction}

This paper investigates market reactions to announcements of farmout agreements by oil and gas companies listed on the Australian Securities Exchange (ASX). Farmout agreements are widely used by oil and gas companies throughout the world to jointly conduct exploration and appraisal activities in the pursuit of economic discoveries of hydrocarbons. Currently there is only descriptive evidence, but no empirical studies, on these types of corporate arrangements. Lowe (1987) defines a farmout agreement in the oil and gas industry as follows:

"An oil and gas farmout agreement is an agreement by one who owns drilling rights to assign all or a portion of those rights to another in return for drilling and testing on the property."

Accordingly, the main objective of undertaking such an interfirm arrangement is to exchange partial exploration rights of the permit owner ("farmor") for benefits to be derived from the exploration activities undertaken by the incoming party ("farminee"). In other words, the farmor agrees to partially transfer working interests over a given area to the farminee in exchange for exploration commitments substantially covered by the latter. ${ }^{1}$

In this paper, we analyse farmout agreements in the context of cooperative arrangements in the financial economics literature. ${ }^{2}$ Although the related definitions vary to some extent, these farmout arrangements meet the broad scope of an alliance being an informal agreement involving at least two separate firms with some level of mutual commitment (Chan, Kensinger, Keown and Martin 1997; Weston and Weaver 2004). As these specific arrangements can take

\footnotetext{
${ }^{1}$ For example, in Appendix 1, on 25 February 2013 Beach Energy (the farmor) announced a farmout agreement with an Australian subsidiary of Chevron Corporation (farminee). In this case, the farmor relinquishes interests over two oil and gas areas located in the states of South Australia and Queensland. Chevron's financial commitment potentially totals up to US\$349 million based on a two-stage work program.

${ }^{2}$ Other oil and gas alliance studies examine bidding strategies for oil leases and market competition (Hendricks and Porter 1992; Mead 1967), bidder information asymmetry (Hendricks, Porter and Boudreau 1987), drilling timing (Hendricks and Porter 1996), production efficiency (Beshears 2013; Kent 1991) and agency theory (Bertrand and Mullainathan 2005). The international legislative framework underpinning farmout agreements is extensive along with oil and gas industry association endorsement of such arrangements in many different countries (Thompson, 2005)
} 
many forms, starting from loosely agreed upon terms through to complex embedded option structures bound by a joint arrangement, the wider concept of alliance (cooperative arrangement or interfirm relationship) embraces this varying level of mutual commitment. Hence, farmouts can take the form of medium-term non-binding agreements between two or more firms, as well as long duration alliances focused on sequential or staged exploration effort of a given oil and gas permit.

We investigate the determinants of wealth changes associated with farmout announcements in light of four theories. First, the 'pooling of resources' theory argues that participants conduct alliances to combine complimentary resources necessary for undertaking the project of interest. Palia, Ravid and Reisel (2007) find evidence of resource pooling in the movie industry setting, in which larger film projects are more likely to be undertaken via alliances. Second, the certification theory assumes that characteristics of the incoming party in a project have the potential to convey quality signals on either the venture prospect or the project vendor. Ozmel, Robinson and Stuart (2013), for instance, find evidence of contributions of past alliances to pharmaceutical companies and venture capitalists to biotech firms' exit outcomes. Third, the expertise theory relies on the use of alliances to transfer technology between participants to undertake a joint project. Beshears (2013) documents evidence supporting the expertise theory in the oil and gas lease-bidding context, where alliances perform better compared to solo companies in drilling outcomes. The fourth hypothesis builds upon real options theory, which considers investment projects as real options due to their sequential nature. Myers (1977) supports the interpretation of real investment projects as call options given that a project's value derives at least partially from sequential or incremental investments.

Evidence on alliance formation in the capital market context is relatively scarce. We contribute to the strategic alliance literature in several ways. Our paper is the first empirical study of the capital market implications of farmout agreements, thus broadening the strategic 
alliance literature with the oil and gas industry. To date, alliance studies on oil and gas firms focus mainly on the strategies used either to bid for oil and gas leases or buy acreage with established oil reserves. Beshears (2013), for example, examines the level of productivity for solo and alliance lease bids based on estimates of economic outputs. ${ }^{3,4}$ Beshears finds evidence consistent with the expertise and information theory as the main determinants of superior alliance productivity. Conversely, McConnell and Nantell (1985) and Chan, Kensinger, Keown and Martin (1997) undertake their alliance investigations by applying an event-study approach to cross-industry samples. They find significant wealth effects around deal announcements, consistent with the synergy hypothesis. However, both these studies are restricted by small sample sizes. ${ }^{5}$ We also note the scarcity of studies applying real options theory to alliances. In the case of farmouts, the farmor is exposed to the risks and benefits arising from the alliance, which is consistent with the sequential (compound) nature of a real investment.

We adopt the event-study approach to examine market reactions to farmout agreements announced by ASX-listed energy firms between 1990 and 2016. The sample comprises 589 and 389 announcements released by farmors and farminees, respectively. Results show that farmout agreements are important economic events, exhibiting an average excess return of $2.51 \%$ for the farmors on the announcement day. The corresponding average market reaction to farminees' announcements is $0.40 \%$. Over a three-day window $[-1,1]$, farmout announcements generate a cumulative average abnormal return of $3.60 \%$, compared with $1.90 \%$ for farminees.

Multivariate analysis of event returns provides evidence consistent with the resource pooling hypothesis. Cross-sectional regression results show that the coefficient on project size,

\footnotetext{
${ }^{3}$ Beshears (2016, p.326) acknowledges systematic measurement error in drilling costs as a study limitation, which could have potentially driven results towards higher alliance productivity.

${ }^{4}$ Oil and gas industry constituents have no product differentiation, so cost structure is an important source of competitive advantage.

${ }^{5}$ McConnell and Nantell (1985) examine 136 joint-venture announcements, while Chan, Kensinger, Keown and Martin (1997) investigate a sample of 345 alliances.
} 
measured by acreage, is positive and significant. Other variables used for testing the resource pooling hypothesis, i.e., financial commitment and the presence of target oil and gas reserve estimate disclosures, are also positively related to abnormal returns. Furthermore, more positive market reactions are observed for farmout permits featuring unconventional targets, suggesting farmors seek partners with expertise to explore more complex prospects. Finally, we provide evidence of a positive association between oil price uncertainty and farmors' abnormal returns, supporting the interpretation that farmouts are real options.

This paper is organized as follows. Section 2 discusses background on the industrial organization of the oil and gas industry. Section 3 reviews relevant literature on cooperative arrangements and develops hypotheses for testing. Section 4 explains the data and research methods used in our empirical tests. Section 5 presents empirical results and conducts sensitivity analysis. Section 6 concludes the paper.

\section{Background of the oil and gas industry}

The oil and gas industry can be divided into three distinct sectors: upstream, midstream and downstream. Upstream activities refer to exploration, evaluation and production phases of hydrocarbon projects and are high-risk. Oil and gas exploration companies are typically equity funded and use their financial resources for exploration with the objective of making an oil and gas discovery. Discoveries, if economical, enable oil and gas explorers to become producers. Exploration rights over oil and gas leases (permits) are usually obtained through winning bids in auctions undertaken by governmental bodies (as in the US) or applied for and leased from the government when vacant (e.g., Australia). Permits are called 'wildcats' or 'greenfields' plays when no prior exploration has been undertaken (Hendricks and Porter 1996).

Midstream oil and gas participants are responsible for storage and movement of oil and gas to downstream processing facilities. For example, midstream firms include logistics planning companies and those operating oil and gas pipeline infrastructure. Downstream participants 
conduct refining, retailing and marketing activities (Rudenno 2012; Tordo, Tracy and Arfaa 2011). Some large companies vertically integrate the whole oil and gas value chain owing to the capital-intensive nature of the industry. These 'major' companies are strategic players given their substantial resource base, including, but not limited to, sophisticated technological expertise in exploration and production, along with extensive oil and gas reserves, pipeline infrastructure, refining capacity and retailing infrastructure.

The form of alliance that we examine in this study, farmout agreements, is a popular type of arrangement for oil and gas exploration projects. According to Lowe (1987), farmouts are of real significance to the oil and gas exploration sector, comparable to the role of oil and gas lease acquisitions. Lowe (1987) explains that such agreements involve at least two parties, of which the farmor ('vendor') holds exploration rights called permits while the farminee ('buyer') seeks to obtain part of the permit's exploration rights in exchange for a financial commitment to the project in the form of exploration/appraisal activities and will normally bear some or even all of the exploration costs otherwise borne by the farmor. Such financial commitments can include: upfront payments to cover sunk costs, obligations to cover (partially or wholly) geological tests in the permit area (e.g., seismic surveys and exploration wells), assumption of permit operatorship, technical assistance, etc. Unlike other industries where alliances are common at different stages of the project, farmouts occur mostly in the early highrisk exploration stage of oil and gas projects. The level of commitment can vary greatly, with some farmouts similar to joint arrangements with binding contracts to enforce mutual obligations, whilst others refer to simple letters of intent. It is clear from our data search over a number of years in the Australian setting that all exploration firms use farmouts arrangements, along with many larger producers. In essence, it is difficult to find industry participants that do not use this type of arrangement. 


\section{Literature review and hypothesis development}

\subsection{Literature on cooperative arrangements}

The study of intercorporate arrangements builds upon seminal studies in the industrial organization literature (Coase 1937, 1990). This literature discusses organizational form and the optimal employment of economic resources. According to Coase (Coase 1937, 1990), the choice of corporate boundaries (institutional structure of production) reflects the relative costs of other firms organizing their activities. Hence, a firm is likely to expand its boundaries until a given level where the cost to process a new transaction is equal to either the market cost of doing so or the cost of executing this specific transaction with another firm. Building upon this theory, the choice of undertaking projects under an interfirm approach has been investigated in the literature. In the capital markets context, some authors observe wealth gains associated with pooling complimentary resources (Brooke and Oliver 2005; Chan, Kensinger, Keown and Martin 1997; McConnell and Nantell 1985; Owen and Yawson 2015), and expertise and technology transfer (Das, Sen and Sengupta 1998). In single-industry studies, there is evidence of positive market reactions to the announcement of interfirm arrangements, with Lerner, Shane and Tsai (2003) finding evidence of alliances as a funding means for biotechnology firms when equity funding is scarce. Robinson and Stuart (2007) also focus on biotechnology firms, finding evidence of the use of equity holdings to allocate control rights in intercorporate arrangement contracts. Berg and Friedman (1977) suggest that exchange of technologies is the main motivation for joint ventures in the chemical industry. Similarly, Koh and Venkatraman (1991) find significant excess returns for companies in the information technology (IT) industry engaging in technology-exchange joint ventures. With respect to the extractive industry, Beshears (2013) finds evidence of superior performance of alliances relative to solo companies in oil drilling projects in the Gulf of Mexico. 
In the following sections, we discuss the main strategic alliance theories and develop hypotheses applicable to farmout agreements. Of relevance is an extensive body of literature focusing on the biotechnology industry, a setting known for the clustering of cooperative arrangements formed at different stages of $R \& D$ projects. The conceptual discussion of real investments and strategic alliances, in light of the real options theory, is developed due to the sequential nature of farmout agreement exploration commitments. Furthermore, the fact the underlying assets of farmout agreements are ultimately oil and gas reserves (or potential reserves) allows investigation employing appropriate proxies for the underlying oil price.

\subsection{Resource pooling theory}

McConnell and Nantell (1985) investigate the wealth effects of joint venture announcements by US companies, testing for synergies arising from resource pooling. The synergy argument suggests the deal ultimately benefits shareholders of all participants, due to more efficient asset employment (Berkovitch and Narayanan 1993; Johnson and Houston 2000). Thus, joint ventures are an appropriate setting to test resource pooling, controlling for the effects of management displacement, as the management of the venture partners remains intact. Similar to oil and gas exploration firms, small biotechnology firms hold portfolios of risky capitalintensive projects and face capital rationing due to their restricted access to funding in the capital markets. Lerner, Shane and Tsai (2003) investigate the shifting sources of project funding for small biotechnology firms. There is evidence suggesting public market conditions are an important determinant prompting the usage of alliances as a financial channel. They find that relinquishment of project control rights is significantly associated with periods where the project owner raises little external financing. The biotechnology sector features the active presence of venture capitalists. However, in contrast to venture capital arrangements, which are used as a tool to capitalise the firm as a whole, alliances with pharmaceutical companies 
are a means through which capital is injected into specific $R \& D$ projects, the rights to which are extensively negotiated with the alliance partner (Robinson and Stuart 2007).

Palia, Ravid and Reisel (2007) investigate co-financing strategies in the movie industry between small production firms and large studios. When film projects reach the 'assembly' stage, most of the necessary inputs, such as budget, casting and project manager, are agreed. At this stage, budget size determines the need for co-financing alliances with other studios. They test the resource pooling hypothesis using a project-level sample comprising 275 film projects over the 1994 to 2000 period. There is evidence that larger film projects, in terms of budget size, are more likely to be undertaken via alliances. The median budget for projects financed via alliances is US\$47.05 million, compared to US\$33.90 million for films solely developed by one production house. Although movie projects have a shorter life than those in the oil and gas and biotechnology settings, studios face challenges allocating limited resources across many projects, hence the attraction of resource pooling.

Oil and gas farmouts are a useful setting for testing the resource pooling theory as firms are likely to engage in co-financing strategies with the common objective of making an oil and gas discoveries. Small oil and gas exploration companies holding exploration permit portfolios may lack the necessary financial resources to explore all their prospects. In contrast, larger companies are interested in participating in risky ventures with potentially high payoffs. Thus, we expect higher excess returns to be associated with farminees' financial commitments disclosed in farmors' announcements. Further, farmors with extant hydrocarbon target estimates are closer to production and would benefit more from farminees able to commercially develop reserves. Thus, we predict farmout agreements with quantitative disclosure of the permit's target hydrocarbon potential to be associated with higher abnormal returns to farmors. In addition, following the rationale of Palia, Ravid and Reisel (2007) suggesting larger projects are more likely to be undertaken via alliances due to their higher demand for resources, we use 
project size to proxy for farmors' needs for resource pooling. We expect project size, as measured by exploration area or acreage, to be positively associated with farmors' abnormal returns. We pose our resource pooling hypotheses as follows.

Hla: Farmors announcing farmout agreements disclosing financial commitments from counterparties are associated with higher abnormal returns.

H1b: Farmors announcing farmout agreements with hydrocarbon reserve targets disclosure experience higher abnormal returns.

H1c: Farmors announcing farmout agreements with interests in larger exploration areas experience higher abnormal returns.

\subsection{Certification theory}

Young firms usually face challenges in signalling their projects' potential to the market. The existence of early-stage projects in young firms' portfolios increases external pressures for operational disclosure to enable market participants to assess firm value in the face of high information asymmetry. Prior studies acknowledge that high information asymmetry stems not only from project uncertainty, but also from small firms' lack of verifiable public information (Leland and Pyle, 1977; Myers and Majluf, 1984). There is ample evidence of certification provided by prestigious investment banks and prominent venture capital firms for initial public offerings (IPOs), applying agency theory featuring moral hazard and hidden information in which information is classified as either hard or soft (Miloud 2016). According to Stein (2002), "hard" information is directly observable by (external) agents, whereas "soft" information cannot be verified due to its qualitative nature. For instance, in the IPO context, the certification conveyed by an experienced and prestigious financial agent (i.e., leading investment bank or venture capitalist) can reduce information asymmetry arising from the issuer's lack of verifiable past track record. 
Stuart, Hoang and Hybels (1999) explore the role of certification in venture capital-backed early-stage biotechnology firms seeking to access capital necessary to undertake R\&D projects. They examine the effects of different exchange partners (alliance partners, equity partners and investment bank) on the biotechnology firm's IPO performance and find evidence of positive alliance partner certification effects on biotech firm valuation. More recently, Ozmel, Robinson and Stuart (2013) test the certification theory, considering the role strategic alliances and venture capital play in biotechnology firms' exit outcomes (either going public or being acquired by another company). The study finds that biotech firms' past alliance track record and being backed by a better positioned venture capitalist increases the likelihood of either exit outcome. This study builds on prior work by Nicholson, Danzon and McCullough (2005), who find evidence of a positive effect of biotech firm alliances with pharmaceutical companies. This earlier work finds that junior biotech firms relinquish, at a significantly discounted price, not only equity interests but also rights to the R\&D projects. However, the discounted value offered by the counterparty is likely to be offset by future higher valuations from venture capitalists and/or investors. Similarly, the operational quality of an oil and gas explorer cannot be observed directly, but a better valuation of its early-stage projects can be obtained when certified by prestigious alliance partners.

Permit information is limited in early-stage exploration where the likelihood of finding hydrocarbons is remote. ${ }^{6}$ Thus, alliance partner characteristics may convey information to the market on the prospectivity of small firms' projects that may otherwise be not observable. Two partner characteristic variables are used to proxy for the certification of project quality, including the origin of the farmout partner (foreign versus domestic oil company) and whether this foreign partner is a 'major' oil company. We pose our certification hypotheses as follows.

\footnotetext{
${ }^{6}$ Paddock, Siegel and Smith $(1988, p .483)$ note the lack of oil and gas lease information at the early exploration stage (bidding stage) as a source of project uncertainty resulting in a wide range of valuations of oil and gas exploration firms.
} 
H2a: Farmors announcing farmout agreements with foreign farminees experience higher abnormal returns.

H2b: Farmors announcing farmout agreements with oil and gas 'majors' experience higher abnormal returns.

\subsection{Expertise hypothesis}

Hayek (1945) discusses how the distribution of knowledge impacts organizational structure and how decision rights are decentralised based on the agents' level of knowledge. Jensen and Meckling (1995) builds upon this study by analysing two main categories of knowledge: specific and general. Specific knowledge refers to specific skills or a particular way to employ economic resources. This type of knowledge is unlikely to be aggregated or summarized; hence its transfer to another agent is deemed to be significantly costly. From this perspective, the main argument is not whether such knowledge transfer is possible, but at what cost such knowledge transfer occurs. Jensen and Meckling (1995) note the importance of whether such transfer is worthwhile based on benefits the knowledge affords managers in making better decisions. In contrast, general knowledge is more available in an organizational network and more easily gained or transferred. The authors emphasize that in a market, as in other societal systems, the decision rights are likely to flow towards the agents that value them most, who, in turn, are likely to be the ones with specific knowledge to use them more efficiently.

In an alliance context, Chan, Kensinger, Keown and Martin (1997) investigate whether alliances involving specific knowledge or proprietary information (proxied by the presence of R\&D) yield higher excess returns to the partner's shareholders, relative to non-R\&D deals. Although there is evidence of significant abnormal returns to both groups, excess returns stemming from R\&D-related alliances are not statistically different from the remainder of the sample. Das, Sen and Sengupta (1998) examine the value creation of technological alliances in a study of 119 non-joint venture arrangements in the US over the period 1987-1991). They 
note the importance of technological arrangements between companies developing early-stage products, mostly involving upstream value chain activities. As such, these alliances are likely to last longer and promote specific knowledge transfer between participants over time. Conversely, marketing cooperation aims to increase extant product demand and/or improving distribution channels. In light of the difficulties of R\&D knowledge transfer, along with increasing competition and rapid technological change in many industries, the authors test the hypothesis that technological arrangements are likely to yield higher excess returns relative to marketing joint-ventures. The authors find evidence supporting this prediction with significantly higher excess returns for firms involved in high-technology deals compared to marketing alliances.

Beshears (2013) examines the performance of oil and gas drilling projects undertaken by alliances and solo firms in the Gulf of Mexico spanning the period 1954-1975. The author investigates bidding prices paid by alliances and solo firms for the rights to explore for hydrocarbons in offshore leases. The main analysis is based on a final sample comprising 1,070 leases won by 563 alliance bids and 507 solo firm bids. The main theoretical explanation motivating the formation of these alliances, when bidding for and executing these projects, is based on the benefits of sharing information and expertise. Accordingly, Beshears (2013) predicts that projects carried out by cooperative arrangements are likely to outperform those undertaken by a single company and find evidence of the superior performance of alliances versus solo companies in drilling outcomes. ${ }^{7}$ Thus, alliance partners contribute expertise in undertaking drilling exploration in areas already exposed to prior exploration effort more efficiently. However, the author also notes the alliance's relative outperformance wanes significantly when it consists of a single high-experience partner. It is suggested that highly complex drilling activities are likely to demand the participation of more than one partner with

\footnotetext{
${ }^{7}$ The experience proxy is based on the number of leases previously held by the exploration companies in the same area of the lease auction.
} 
a high level of specific knowledge, in this case offshore exploration expertise. This result contrasts univariate evidence in Kent (1991), who investigates data on lease permit bidding and exploration output over 1954-1973. This earlier study finds no significant difference in performance between exploration projects undertaken by joint ventures versus solo companies.

In the farmout context, we test the technology and expertise hypothesis using three projectlevel proxies. First, an important characteristic of oil and gas exploration projects is the nature of the rock type subject to exploration and the drilling techniques required to access any oil and gas targets. Conventional resources accumulate in well-defined reservoirs whose exploration is possible using simple drilling techniques. In contrast, unconventional hydrocarbons are found in rocks with lower levels of permeability and porosity, requiring complex drilling techniques, such as the use of horizontal wells and hydraulic fracturing (Zou 2017). Although project complexity for both types of exploration approach varies significantly, unconventional resources pose specific challenges, such as the need for ongoing appraisal effort and related expenditures, and higher environmental risk (Sweeny, Cody, Lindberg and Darden 2013). Thus, permits containing unconventional exploration targets will motivate farmors to seek more experienced partners.

Second, oil and gas exploration activity is broadly divided into two types: offshore and onshore. Following Beshears (2013), offshore oil and gas projects are regarded as more complex. Technology and experience are key factors in offshore exploration as targets may be located at significant depths. Thus, our second proxy is the presence of offshore permits subject to the farmout agreement. We argue that farmors are likely to seek partners with higher technological capabilities to undertake deeper offshore exploration. Furthermore, farmors may elect to relinquish control rights over the day-to-day exploration management of the permit in favour of the farminee, referred to as a change in project operatorship. We pose the following testable hypothesis. 
H3a: Farmors announcing farmout agreements targeting unconventional resources experience higher abnormal returns.

H3b: Farmors announcing farmout agreements over offshore tracts experience higher abnormal returns.

H3c: Farmors announcing farmout agreements where project operatorship is relinquished experience higher abnormal returns.

\subsection{Farmout agreements as real options}

Geske (1979) explores the concept of compound options illustrated with a call option on a firm's stock, as the stock per se can be regarded as an option on the firm's asset value. As such, the call option is regarded as "an option on an option". Likewise, farmout agreements meet the definition of a compound option as:

\section{“(...) an opportunity with a sequential nature, where later opportunities are available only if earlier opportunities are undertaken." (Geske 1979, p.63)}

Myers (1977) considers whether a real investment project can be regarded as a call option given the project's value derives at least partially from sequential incremental investments. A project's value is derived from the cash flows generated by the assets in place and those afforded by a discretionary future expansion and/or asset redeployment. The value of assets in place can be calculated from conventional valuation approaches (i.e., discounted cash flows). Valuing future expansion possibilities demands a more sophisticated valuation approach due mostly to the embedded flexibility to undertake, or not, sequential actions. This is considered the option growth value. The development of this real option valuation theory fostered a body of literature focused on valuation of extractive industry projects (Brennan and Schwartz 1985; Moel and Tufano 2002; Paddock, Siegel and Smith 1988; Tourinho 1979). Brennan and Schwartz (1985) consider the stochastic nature of the output (commodity) price as well as the 
importance of management flexibility to face the commodity price variation, given the significant volatility observed in some commodity prices at that time. ${ }^{8}$

Paddock, Siegel and Smith (1988) and Cortazar and Schwartz (1997) focus on the development of valuation models for real options on undeveloped oil fields. Both studies note the importance of identifying the distinct project's life-cycle stages, with the compound nature of investments in offshore oil leases made up of three distinct phases: exploration, development and extraction. Paddock, Siegel and Smith (1988) note the high level of uncertainty in the exploration stage for which geological and technical information is necessary to assess the prospect's potential. Cortazar and Schwartz (1997) emphasise the use of future prices to avoid variability stemming from spot price predictions. Both studies indicate the relevance of project timing (flexibility) as one of the determinants of real option value, with flexibility allowing managers to decide the timing of field exploration based on commodity prices. Cortazar and Schwartz (1997) find evidence that fractional value attributed to the waiting option is negatively related to oil prices. In other words, the higher the oil price, the lower the option value related to 'waiting'.

In terms of interfirm collaboration, Kogut (1991) views joint ventures as real options with firms seeking partners to share uncertainty and exploit efficiencies. Kogut (1991) considers two possible venture outcomes as the real option exercise: either the venture being acquired by one of the parties or its ultimate termination. He finds that increases in venture value stemming from unexpected industry growth increases the likelihood of option exercise through acquisition. Folta and Miller (2002) examine buyouts and incremental equity acquisitions by companies holding initial equity stakes in small biotechnology firms. The authors consider the initial equity acquisition as the option premium for companies accessing R\&D projects undertaken by capital-constrained biotechnology firms. From this perspective, the option is

\footnotetext{
${ }^{8}$ For example, Bodie and Rosansky (1980) report that standard deviation of the futures prices for cooper, silver and platinum over $1950-1976$ reached $47.2 \%, 25.6 \%$ and $25.2 \%$, respectively.
} 
only exercised when the former acquires the latter's controlling interest. By applying the BlackScholes' valuation model, the authors analyse the flexibility and commitment trade-off arising from the acquirer's decision to further increase equity ties. Where the right to purchase the biotech firm's controlling interests is not exclusive, the acquirer's waiting option value is less obvious due to the likelihood of other companies bidding for the same target. Their main finding suggests that in times of low uncertainty, buyout options are more likely to be exercised if the acquirer has more exclusive rights. However, when biotechnology firms have equity collaborations with larger companies where the outright acquisition rights are shared, the likelihood of buyouts increases even in times of high uncertainty.

In the oil and gas context, Sabet and Heaney (2016) test the relation between oil acreage and reserve acquisitions using real options theory. They regard acreage and reserves as real options for which the compound component is higher for acreage due to the incremental flexibility to explore and, conditional on hydrocarbon presence, exploit production opportunities. Hence, they expect the acquiring firm's market reaction to be higher for acreage purchases relative to reserves. They find evidence confirming energy firm's stock prices are more sensitive to the volatility of oil prices for acreage compared to reserve purchases suggesting the embedded waiting option present in the acreage acquisitions has a substantial value once oil price volatility increases. This allows the acquirer to decide the optimal timing of further exploration investments. In contrast, they argue that reserves only confer on the acquirer the option to extract hydrocarbon resources once they become commercially viable. ${ }^{9}$ In the farmout alliance context, the party relinquishing interests in the project is still exposed to the risks and benefits arising from the staged project exploration. We use crude oil price volatility as a proxy for the uncertainty related to the underlying commodity price, to which farmors remain partially exposed. We pose the following testable hypothesis.

\footnotetext{
${ }^{9}$ It is noted that oil and gas reserves convey the same waiting option value arising from oil and gas company's discretion as to when they should be exploited, which is dependent on the oil price, a prediction not confirmed by Sabet and Heaney (2016).
} 
H4: Farmors announcing farmout agreements in periods with higher crude oil price volatility experience higher abnormal returns.

\section{Data and method}

\subsection{Data}

Farmout announcements by ASX-listed oil and gas firms are manually collected over the period January 1990-December 2016. Two data sources are used to search for these announcements, viz., Morningstar's Datanalysis Premium ${ }^{10}$ and Factiva. Search on these databases has the advantage of including delisted firms, which assists in mitigating survival bias. The search for farmouts follows a two-step process. The first step queries Morningstar's Datanalysis Premium database, which contains searchable ASX full-text announcements over the sample period. ${ }^{11}$ The second step involves repeating the same process using Factiva over the period from 1990 to 2000 (during this period Morningstar's Datanalysis Premium has limitations in terms of searchable announcement text). ${ }^{12}$ Cases involving an ASX-listed non-energy farminee are retained. ${ }^{13}$ A total of 2,449 announcements are identified, with sample attrition documented in Table 1. Following Chan, Kensinger, Keown and Martin (1997), only the initial or first announcement of the deal to the ASX is included. Typically, deal conclusion may take months and involve a number of sequential announcements. We employ a project identifier to track deal announcement histories, which enables us to identify initial and subsequent deal

\footnotetext{
${ }^{10}$ GICS code 1010 is used to search documents reported by companies from the energy industry.

11 Queries included "farm in", "farm out", "farmin" and "farmout". Subsequently, it was observed that some valid announcements were being missed due to the idiosyncratic nature of some disclosure. Slightly broader and more generic search criteria were applied. All ASX-listed energy firms' announcement headlines were analysed with: (i) a VBA query employed to identify headlines containing the word "farm"; (ii) content analysis undertaken focusing on some related keywords ("expansion", "agreement", "new acreage" and "new investment").

12 The keywords used are "farmout" and "farmin" with the following source filters: (i) four sectors in the energy industry (Crude Oil/Natural Gas Upstream Operations, Downstream Operations, Natural Gas Processing, and Oil/Natural Gas Midstream Operations), and (ii) news source limited to the Australian Stock Exchange Company Announcements.

${ }^{13}$ For example, on 14/07/1994, The Broken Hill Proprietary Company Limited (BHP) announced a farmout agreement with two farminees, namely Mobil Exploration \& Producing Australia Pty Ltd and Indonesia Petroleum Ltd, over two permits located in Western Australia. Although BHP's principal business is mineral exploration and production (Materials), the company has significant exposure to oil and gas projects through its subsidiary, BHP Petroleum Pty Ltd. In terms of frequency, there are $14(2.4 \%)$ farmouts from firms in the Materials industry, which, like the BHP example, undertake oil and gas projects as a secondary economic activity. Regarding farminees, there are 33 announcements (8.5\%) from non-energy firms classified in five different industries, with Materials the most frequent classification having 23 farmins $(5.9 \%)$.
} 
announcements. ${ }^{14}$ After excluding 1,447 subsequent announcements, another 18 transactions are deemed not to be farmouts and a further six announcements are deemed as lacking sufficient details. The final sample consists of 978 announcements, comprising 589 disclosed by farmors or 'vendors' and 389 disclosed by farminees or 'buyers'. These companies participate in 722 unique farmout deals as some of the agreements involve more than one ASX-listed companies. [Insert Table 1 about here]

Table 2 reports the distribution of farmout agreements by year. The highest frequency of deals is observed in the years 2006 (53), 2007 (60) and 2010 (54). Farmors are more active in the years 2005 (51), 2006 (48) and 2007 (49), While farminees are most active in 2007 (35), followed by 24 deals announced in 2005, 2009 and 2010. Overall, a more active market for farmouts occurred in mid-2000s through 2010, with an increase in 2012 corresponding to periods of higher oil prices. ${ }^{15}$

[Insert Table 2 about here]

Table 3 reports descriptive statistics for our farmout sample. ${ }^{16}$ In terms of firm-level variables, the size of farmout participants is measured by their market capitalization in Australian dollars at the end of the fiscal year prior to the announcement $(M C A P)$. Farmors have a mean (median) market capitalization of $\$ 469.1$ million (\$23.7 million). In contrast, farminees are larger, with a mean (median) market capitalization of $\$ 2,077.0$ million (\$29.0 million). The MCAP distribution indicates skewness to the right due to the presence of relatively large companies, including 47 non-energy participants. ${ }^{17}$ FIRMAGE is firm age,

\footnotetext{
${ }^{14}$ Appendix 2 provides an example of a farmout chronology announced by an ASX-listed energy firm, New Guinea Energy Ltd. The initial announcement was released on 20/07/2009, disclosing the preliminary deal terms. Subsequently, four announcements were released over the following three months disclosing further details, including the Papua New Guinea government's permit approvals. Thus, it is possible to identify the date when the farmout deal became public.

${ }^{15}$ Farmout numbers are highly correlated with one-year leading futures prices for West Texas Intermediate (WTI) Crude.

16 This paper primarily considers farmor announcements and their motivations to relinquish permit interest based on project and partner characteristics. Data on farminees are provided for descriptive purposes given there is no descriptive evidence available to date in the literature.

17 The mean (median) market capitalization of non-energy farmors is $\$ 9,452.9$ million (\$27.3 million) compared to $\$ 265.7$ million (\$23.4 million) of oil and gas farmors. Similarly, non-energy farminees are larger with a mean (median) market capitalization of $\$ 10,478.0$ million (\$23.7 million) compared to the mean (median) MCAP of oil and gas farminees of \$1,343.4 million (\$29.4 million).
} 
measured as the time, in years, between a firm's listing date on ASX and the farmout announcement date. Farmors in the sample are listed for a mean (median) of 12.6 (9.1) years. This compares with the farminees' mean (median) age of 17.7 (11.8) years, suggesting farminees are relatively older. The variable TOP20 captures shareholder concentration, measured by the equity stake held by the twenty largest shareholders sourced from annual reports in the prior fiscal year. The top twenty shareholders hold a mean (median) stake of $49.6 \%(49.7 \%)$ of farmors' equity, compared to $53.2 \%$ (51.4\%) for farminees, respectively.

[Insert Table 3 about here]

In terms of project-level variables for our sample of 722 unique projects, NFIRMS indicates the number of parties to a farmout agreement. A mean (median) NFIRMS of 2.2 (2.0) suggests that the average deal involves only one farmor and one farminee. ${ }^{18}$ For farmout announcements released by both farmors and farminees, the maximum number of participants is 5. Extant literature on mergers and acquisitions includes measures of political uncertainty of the target (Glambosky, Gleason and Murdock 2015). To control for political risk inherent to project locations, we extract data from the PRS Group's International Country Risk Guide covering 141 jurisdictions $(C R I S K) .{ }^{19}$ For our sample, farmors relinquish interests in projects located in jurisdictions with an average (median) political risk of $0.81(0.88)$. This political risk index is employed due to its broad coverage and has been used by Glambosky, Gleason and Murdock (2015) to measure risk of loss due to weakness in the legal system, expropriation, bureaucratic

\footnotetext{
${ }^{18}$ Although some permits are held by many oil and gas companies prior to the farmout agreement, only the active agreeing parties are considered in the sample based on the announcement disclosure. For example, if prior to the agreement the permit is held by two companies of which only one is seeking another partner for a farmout agreement, the announcement is usually clear which permit holder is relinquishing interests to the incoming party (farminee). Therefore, only the two agreeing parties are considered in the deal. It is important to note that in some cases, the farminee's identity is missing due to confidentiality provisions or insufficient disclosure.

${ }^{19}$ The PRS political risk measure ranges from zero to one, with a higher value indicating lower risk. It is composed of six risk dimensions: voice and accountability, political stability and absence of violence, government effectiveness, regulatory quality, rule of law and control of corruption. In this study, the average of all these six dimensions in the year prior to the farmout announcement date is used. Index figures for the year 1997 is allocated to projects in prior years due to the limited data coverage for the 1990-1996 period, with a similar approach used for any other missing data. For countries with incomplete data, the average index year closest to the announcement date is used. The following countries are not covered by PRS over the full sample period: Mauritania, Timor, Seychelles, Kyrgyzstan and the Republic of Georgia. French Guiana's index mirrors France as the former is part of France's overseas territories. This approach is consistent with Kogut (1991).
} 
hurdles and repudiation of debt in their study of cross-border acquisitions. Permit area (ACREAGE) is measured in acres and disclosed for a total of 566 permits. The mean (median) permit size is $2,048,124(489,763)$ acres, indicating the presence of vast acreages in some agreements. Oil price data is obtained from the US Energy Information Administration for the WTI futures contract. ${ }^{20}$ We calculate oil price volatility $(O I L P V O L)$ based on the daily price change over the month of the famout announcement (Grullon, Lyandres and Zhdanov 2012; Sabet and Heaney 2016). The mean (median) volatility is $0.02(0.02)$ for the 722 unique deals announced. Additionally, there are periods in which the oil price volatility reached nearly 0.08 during the commodities boom and falling to a low of 0.01 in years where oil prices were depressed. Such large variance is expected given the sample spans 27 years and complete oil price cycles are observed.

Table 3 also reports frequency counts for our project-level indicator variables. There are 318 (44.0\%) farmout announcements specifying financial commitments underpinning the alliance $($ FINCOM $)$. We include an indicator variable to control for potential permit recycling where a permit is being subject to many separate farmout agreements over time. There are $522(61.2 \%)$ unique farmout agreements for which the exploration permit(s) is(are) farmed out for the first time (FIRSTFARM). In terms of participation by foreign (non-Australian) companies, Table 3 shows $377(52.2 \%)$ of the agreements involve at least one foreign farminee (FOREIPART). In addition, $40(5.5 \%)$ of all agreements involve an oil and gas 'major' participant (MAJORPART) as farminee. We define an oil and gas 'major' in the following way. First, a ranking of the twenty largest energy companies based on total oil and gas revenues is obtained using Factiva. ${ }^{21}$ This list of 20 companies is modified based on: (i) company's primary industry classification to capture firms operating mostly in the upstream sector using segment reporting, and (ii) the

\footnotetext{
${ }^{20}$ Data available at U.S. Energy Information Administration's website: www.eia.gov.

${ }^{21}$ Factiva's peer comparison tool enables selection of the energy industry, based on the Dow Jones Industry Classification. The rankings are based on 2016 fiscal year's total sales from Factiva's peer comparison.
} 
presence of at least one overseas project. ${ }^{22}$ Appendix 3 shows 13 oil and gas companies matching these criteria.

There are $318(44.0 \%)$ farmout agreements containing permit areas subject to offshore exploration $($ OFFSHORE $) .{ }^{23}$ The operator of a project has day-to-day decision-making rights over the project. There are a total of 410 unique agreements disclosing operatorship, of which $156(38 \%)$ indicate a change of operatorship to the farminee (OPERCHANG). Some 327 (45.3\%) of the farmout agreements involve permits where holders have conducted sufficient work to estimate potential target resources (POTENRES). In terms of resource complexity, there are $94(13.0 \%)$ agreements with unconventional targets (UNCONV). Furthermore, 325 $(45.0 \%)$ of the farmout projects are located overseas (PROJLOC).

\subsection{Event-study approach}

We adopt the event-study approach of Ball and Brown (1968) and Fama, Fisher, Jensen and Roll (1969) to assess market reactions to farmout announcements by farmors and farminees. Under ASX's continuous disclosure requirement, oil and gas farmout announcements have precise date and time stamps available on ASX's company announcement platform. A marketadjusted model is employed to calculate abnormal returns around the announcement day as follows: $:^{24}$

$$
A R_{i, t}=\ln \left[\frac{P_{i, t}}{P_{i, t-1}}\right]-\ln \left[\frac{P_{m, t}}{P_{m, t-1}}\right]
$$

Abnormal or excess returns $(A R \mathrm{~s})$ are calculated as the difference between the log price relatives of the announcing firm $\left(P_{i}\right)$ and the ASX All Ordinaries market index $\left(P_{m}\right)$. Both price relatives are adjusted for dividends and other distributions. ARs are cumulated $(C A R \mathrm{~s})$ over a three-day event window centred on the farmout announcement day as follows:

\footnotetext{
${ }^{22}$ Crude Oil/Natural Gas Upstream Operations (SIC code 1311) or Oil and Gas Field Exploration Services (SIC code 1382).

${ }^{23}$ Annual reports from announcing firms are used to identify exploration type when not disclosed in the farmout agreement.

${ }^{24}$ This benchmark ensures minimal data attrition, considering the significant number of small firms in the sample. Further, daily data on Fama-French-Cahart factors are not available for the Australian market (Ferguson and Lam 2016, p.106).
} 


$$
\operatorname{CAR}_{i}(-1,1)=\sum_{t=-1}^{1} A R_{i, t}
$$

Stock prices for ASX announcing firms are obtained from Datastream for $92.5 \%$ of the sample, with the remainder sourced from the Securities Industry Research Centre of AsiaPacific (SIRCA) Core Research Data (CRD) database. The benchmark All Ordinaries Index used to calculate abnormal returns is based on the market capitalisation of the 500 largest firms listed on $\mathrm{ASX} .{ }^{25}$ Market capitalization data $(M C A P)$ for announcing firms is obtained at the fiscal year-end prior to the farmout announcement from Datastream. ${ }^{26}$

In conducting the event study, we need a sample of announcements that are not plagued by other confounding announcements, missing stock prices or non-synchronous trading over the three-day event window. To this end, we exclude the following from our announcement sample: (i) late farmout announcements that are pre-empted by an earlier announcement released by the counterparty, (ii) farmout announcements that contains non-related material transactions, (iii) multiple farmout announcements released by the same party on the same date relating to the same deal, and (iv) farmout announcements associated with firm capitalization changes,${ }^{27}$ non-trading, missing stock prices over the three-day event window. This leaves 505 farmor and 317 farminee announcements remaining in the event study sample.

Contemporaneous events violate the assumption of cross-sectional independence of returns. An advantage of this setting is that farmouts announcements are not time clustered (see Table 2). To mitigate any further concerns of cross-sectional independence of returns, all significance tests ('t $t$-tests') are reported following Kolari and Pynnonen (2010) for both abnormal and cumulative abnormal returns.

\footnotetext{
${ }^{25}$ The "All Ordinaries" or simply "All Ords" index is available on Datastream under the ticker ASXAORD from 29/05/1992 onwards. Prior to this date, this market index is identified as AUSTOLD in the database.

${ }^{26}$ Market capitalization data is sourced from Datastream (90\%), Morningstar's Datanalysis Premium (7\%) and firm's annual reports (3\%)

${ }^{27}$ E.g., equity issues, private placements, share buybacks and share purchase plans.
} 


\subsection{Cross-sectional model}

To explore how wealth effects from farmout announcements vary across the sample with firm and project characteristics, the following ordinary least square (OLS) regression model is specified:

$$
\begin{aligned}
\text { CAR }(-1,1)= & \beta_{0}+\beta_{1} \text { FINCOM }+\beta_{2} \text { FOREIPART }+\beta_{3} \text { UNCONV }+\beta_{4} \text { OILPVOL } \\
& +\beta_{5} \text { FIRSTFARM }+\beta_{6} \text { CRISK }+\beta_{7} \text { NFIRMS }+\beta_{8} L M C A P+\beta_{9} \text { TOP } 20 \\
& +\beta_{10} \text { LFIRMAGE }+e
\end{aligned}
$$

where the dependent variable is the three-day cumulative abnormal return over the event window. Note that we implement the above cross-sectional model to the sample of farmor announcements only. This is because many of the farminees are foreign companies and their level of disclosure is not as high as for ASX-listed firms. The lack of details in their announcements result in severe data attrition problem for the sample of farminees.

We include experimental variables to test our hypotheses developed in Section 3. To test the resource pooling hypothesis, we include FINCOM, an indicator variable for the presence of financial commitment terms in the farmout announcement in the model (H1a). As alternative measures, we also use POTENRES (for $\mathrm{H} 1 \mathrm{~b}$ ), an indicator variable for the disclosure of potential reserve targets in the permit area, and LACRES (for H1c), the natural logarithm of permit acreage, to proxy for resource pooling. For all three proxies, a positive and significant coefficient would provide support of the resource pooling hypothesis.

The certification hypothesis is examined by using FOREIPART (for H2a), an indicator variable for foreign farminee, and MAJORPART (for $\mathrm{H} 2 \mathrm{~b}$ ), an indicator variable for farminee being an oil and gas 'major' company. If foreign or 'major' farminees provide certification to farmors announcing the deal, we should observe a positive and significant coefficient for these two variables. 
To explore the expertise hypothesis, three test variables are used. UNCONV is an indicator variable for farmout projects targeting unconventional resources (for H3a). OFFSHORE is an indicator variable for the presence of permit areas subject to offshore exploration (for $\mathrm{H} 3 \mathrm{~b}$ ). OPERACHANG is an indicator variable for disclosure of permit operatorship change (for $\mathrm{H} 3 \mathrm{c}$ ). A positive and significant coefficient for these three proxies of farminee expertise would lend support to the expertise hypothesis. Finally, to test $\mathrm{H} 4$ (on real options), we include a continuous variable $O I L P V O L$ to proxy for the volatility of crude oil prices.

In addition to the test variables, we also include variables to control for other firm and project characteristics in the model. FIRSTFARM is an indicator variable to control for projects farmed out for the first time. CRISK is a continuous variable to control for political risks of the jurisdiction where the permit is located using the PRS political risk index. NFIRMS is a continuous variable controlling for the total number of farmout participants disclosed in the announcement. $L M C A P$ is the natural logarithm of the announcing firm's market capitalization at the fiscal year-end prior to the farmout announcement. TOP 20 is the equity stake held by the twenty largest shareholders in the announcing firm to control for shareholder monitoring. We also control for differences in firm age in logarithmic form (LFIRMAGE) across the sample of announcing firms.

Table 4 reports Pearson correlation coefficients for firm- and project-level variables for the sample of farmor announcements. FIRMAGE, MCAP and ACRES are logged (LFIRMAGE, LMCAP and LACRES, respectively) due to skewness. LFIRMAGE and LMCAP are positively correlated. This indicates the longer a farmor is listed, the higher its market capitalization. The country political risk of farmout projects $(C R I S K)$ is negatively correlated with acreage (LACRES), suggesting farmors relinquish smaller acreages in less risky countries. ${ }^{28}$ Similarly, farmouts with foreign farminees (FOREIPART) are negatively associated with project

\footnotetext{
${ }^{28}$ Recall that a higher CRISK measure indicates lower risk. See discussion in Section 4.1 on data.
} 
country's political risk (CRISK), indicating farmors seek foreign partners to undertake projects located in high risk countries. Offshore projects (OFFSHORE) are positively correlated with foreign partners (FOREIPART), suggesting that farmors seek foreign farminees to undertake offshore exploration. Projects targeting unconventional resources (UNCONV) are negatively correlated with offshore exploration (OFFSHORE), implying unconventional resources are primarily located onshore. Project location (PROJLOC) is negatively correlated with project country's political risk (CRISK), suggesting farmors relinquish interests in overseas projects in countries with high political risks. This result is intuitive as projects located in Australia are assumed to be of low risk. PROJLOC is positively associated with foreign partners, suggesting farmors attract overseas farminees to undertake projects located in countries outside Australia.

[Insert Table 4 about here]

\section{Results}

5.1 Market reaction to announcements of farmout agreements

Descriptive statistics on market reactions to farmout announcements released by farmors and farminees are reported in Table 5, Panel A, which presents daily abnormal returns from five days before to five days after the announcement. Our discussion focuses primarily on the threeday event window $[-1,1]$. There is evidence suggesting that farmout agreements are significant market events for farmors, who experience a mean abnormal return of $2.51 \%$ on the announcement date (significant at the $p<0.01$ level). On the day prior (day -1$)$, there is also evidence of a positive and significant mean abnormal returns of $0.63 \%(p<0.10)$. The mean abnormal return in the day after is $0.41 \%$, but not significant. We also note that $A A R$ in the remaining days over the 11-day event window is of much lower magnitude and statistically insignificant from zero. The percentage positive statistic is $53 \%, 59 \%$ and $49 \%$ over each of the three event days, respectively. 
As for farminees, Table 5 (Panel A) shows some evidence of market anticipation, with day prior to announcement (day -1$)$ recording a positive and statistically significant mean abnormal return of $1.53 \%(p<0.01)$. This result is in contrast to the less significant mean abnormal return of $0.40 \%$ on the event day $(p<0.10)$. The day following the announcement exhibits a mean abnormal return of $0.05 \%$, but not significant. The percentage positive statistic for farminees over the three days in the event window is $54 \%, 54 \%$ and $46 \%$, respectively. Univariate tests confirm farmout announcements are more significant economic events for farmors than for farminees, with the difference in mean abnormal returns highly significant at the $p<0.01$ level on the announcement day. Table 5 (Panel B) reports further descriptive statistics on the distribution of abnormal returns on announcements released by farmors and farminees.

\section{[Insert Table 5 about here]}

The abnormal returns observed for our sample of farmouts are slightly stronger than for prior studies of alliances and joint ventures. For example, a positive and significant mean abnormal return of $0.64 \%$ is observed in the alliance study by Chan, Kensinger, Keown and Martin (1997), and a mean two-day excess return of $0.73 \%$ is observed in the study of joint ventures by McConnell and Nantell (1985). Our count of positive abnormal returns on the announcement day of $59 \%$ is similar to the $55 \%$ and $67 \%$ observed by Chan, Kensinger, Keown and Martin (1997) and McConnell and Nantell (1985), respectively. Further, when compared to other single-industry studies, Sabet and Heaney (2016) find an average positive abnormal return of $0.53 \%$ for oil and gas firms announcing acreage and reserve acquisitions. ${ }^{29}$ Given that farmors are relatively smaller companies, it is not surprising that farmout agreements yield a higher abnormal return. In contrast to acreage and reserve outright acquisitions in which all project's risks and benefits are transferred to the acquirer (Sabet and Heaney 2016), farmouts allow participants to partially share risks and benefits inherent in the ongoing exploration.

\footnotetext{
${ }^{29}$ The three aforementioned studies do not provide descriptive data on the abnormal return distribution, not allowing the comparison of median and of other data points.
} 
Table 6, Panel A reports cumulative average abnormal returns (CAARs) observed for farmout announcements, which confirm both economic and statistical significance of these events. The three-day average $C A R$ is $3.60 \%$ ( $p<0.01$ ), with a count positive of $61 \%$. Farminees also experience a positive and statistically significant mean wealth effect over the 3-day event window of $1.90 \%(p<0.01)$, but is significantly lower than farmouts but remains statistically significant at $p<0.01$ level. The farminee event-window count positive is $54 \%$. Table 6 , Panel B depicts the distribution of farmout $C A R$ s, showing a median three-day $C A R$ of $1.67 \%$ and $0.27 \%$ for farmors and farminees, respectively. Univariate tests (Panel A) confirm CAARs are significantly greater for farmors than for farminees across all three event windows.

\section{[Insert Table 6 about here]}

\subsection{Determinants of abnormal returns}

Table 7 depicts OLS regression results for the primary model in Equation (3) and modified specifications based on alternative proxies for each hypothesis. In terms of control variables, Table 7 shows the three-day cumulative abnormal returns are negatively related to firm size $(L M C A P)$ of the farmors and the result is statistically significant across different specifications of the model. This result is not surprising given that wealth effect of farmouts is measured as a percentage of firm market capitalization. Firm age (LFIRMAGE) is another control variable that is significantly related to the event $C A R$ across model specifications. The positive coefficient on firm age suggests the older the farmor announcing the deal, the higher the abnormal return.

Regression results from Table 7 (Columns 1-3) provide evidence consistent with the 'resource pooling' hypothesis. Column (1) shows the coefficient on FINCOM is positive (0.028) and significant at the $p<0.01$ level, indicating the exchange of permit interests for disclosed financial commitments results in higher abnormal returns for the farmor due to capital constraints faced by smaller oil and gas farmor participants (H1a). In Column (2), the positive 
(0.020) and significant $(p<0.05)$ coefficient on POTENRES lends further support to the prediction that farmout agreements with existing hydrocarbon reserve estimates, being closer to production, would gain more from contributions by farminees in filling the funding gap for further development (H1b). In addition, Column (3) reveals the coefficient on LACRES (i.e., farmout permit acreage) is positive $(0.007)$ and significant at the $p<0.05$ level. This finding suggests larger wealth effects to farmors relinquishing interests in larger permits, consistent with the prediction of $\mathrm{H} 1 \mathrm{c}$.

\section{[Insert Table 7 about here]}

In the certification hypothesis, we argue that the presence of foreign farminees (FOREIPART), and particularly 'major' oil and gas farminees (MAJORPART) would result in a higher abnormal return to the farmor because of the certification effect provided by these reputable participants in signalling the quality of the prospect. Results from Columns (1) and (4) show that the coefficient on both FOREIPART (H2a) and MAJORPART $(\mathrm{H} 2 \mathrm{~b})$ is positive but not statistically significant. We also note that FOREIPART is also not significant in other model specifications in Table 7. Thus, this study finds no support for the certification hypothesis.

Our expertise hypothesis is tested by using three proxy variables: UNCOV (H3a), OFFSHORE (H3b) and OPERCHANG (H3c). Regression results from Table 7 show that there is a positive relation between projects targeting unconventional resources and farmor's abnormal return on farmout announcement. For instance, Column (1) s reveals a positive $(0.026)$ and significant $(p<0.10)$ coefficient on UNCONV in the primary model, which is also observed when alternative models are specified (Columns 2 and 4). This evidence tends to support the expertise hypothesis (H3a). When alternative proxies for expertise are employed in the model, no significant association with abnormal returns can be found. Specifically, Column (5) shows the estimated coefficient on OFFSHORE is negative (-0.009) but not 
significant. This is inconsistent with the prediction of $\mathrm{H} 3 \mathrm{~b}$ that projects requiring offshore exploration would potentially attract farminees with greater expertise and thus a positive wealth effect. When change in project operatorship (OPERCHANG) is used, Column (6) shows a positive (0.014) but insignificant coefficient on OPERCHANG, leading to hypothesis $\mathrm{H} 3 \mathrm{c}$ not being supported. The lower level of disclosure for change in operatorship in farmout agreements restricts the sample size in this model specification to 274 observations. ${ }^{30}$

With regard to the real options hypothesis (H4), the oil price volatility (OILPVOL) coefficient is positive and significant at $p<0.01$ across all model specifications, except Column (6), where the sample is restricted to 274 observations. This finding is strongly consistent with the real options theory as farmors remain exposed to the project with residual or trailing interests after the farmout.

\subsection{Sensitivity analysis}

We subject our main results from Table 7 to a battery of sensitivity analysis. Event studies are prone to the impact of confounding noise. Thus, we control for noise from other firm-level price sensitive announcements released over the three-day farmout event window. We find that there are 134 (231) farmout agreements with one or more market sensitive announcements on the event day (over the three-day window) or data is not available from ASX. We re-run the primary model (Equation 3) after removing these announcements with confounding noise and the results are reported in Table 8. As Column (1) indicates the model's explanatory power more than doubles to $13.3 \%$ (5.9\% in Table 7 Column 1).The coefficients on three experimental variables for this model (FINCOM, FOREIPART and OILPVOL) are larger than those reported in Table 7. However, the coefficient on $U N C O N V$ is no longer significant. Results are similar to those reported in Column (1) when we exclude 231 farmout agreements with contemporaneous price sensitive announcements over the three-day event window from the

\footnotetext{
${ }^{30}$ This sample comprises farmor announcements disclosing permit's operatorship status.
} 
sample (Column 2) and when we include a count of the number of contemporaneous price sensitive announcements in the model (Column 3).

[Insert Table 8 about here]

We also re-run the regression analysis in Table 7 by using robust standard errors clustered by firm and year. Untabulated results indicate no change in the significance level for the experimental variables: FINCOM, POTENRES and LACRES. However, UNCONV is now only significant at $p<0.10$ (Column 2) and the significance of $O I L P V O L$ drops to the $p<0.05$ level for model specifications in Column (1), (3) and (4). Thus, controlling for robust standard errors does not significantly change the main results.

\section{Conclusion}

Our study is the first to examine empirically the wealth effects stemming from farmout announcements by energy companies. These alliances are common in the oil and gas sector. Using a hand-collected Australian sample of farmout agreements, we find that farmors ("vendors") are smaller and younger than farminees("buyers"). We also provide evidence showing that farmouts are important economic events in a market context, attracting a positive mean cumulative abnormal return of $3.60 \%$ over a three-day event window to farmors, which is greater than the wealth effect of $1.9 \%$ to farminees.

Cross-sectional analysis of $C A R[-1,1]$ indicates the importance of funding commitments, confirming the resource pooling hypothesis and consistent with the use of alliances as a financing channel as observed in the biotech setting. Further evidence is found for the resource pooling theory in farmouts disclosing target reserve estimates as well as with deals featuring larger permit acreage, both exhibiting higher abnormal returns. This evidence on resource pooling is similar to prior alliance studies of movie studios, which suggest larger film projects are more likely to prompt alliances where filmmakers combine complimentary resources. In regards to the certification theory, no evidence is found. A third hypothesis tests for the 
technology and expertise motivation of farmouts. We provide evidence of farmors relinquishing interests in permits with unconventional reserves experiencing higher excess returns, although it is significant only at the $10 \%$ level. Farmouts can be argued to be an ideal setting for testing the real options theory given the sequential nature of oil and gas exploration commitments. Using volatility of crude oil price as a proxy for uncertainty, we find statistical evidence that farmout agreements announced in years with higher oil price volatility yield higher abnormal returns, consistent with Sabet and Heaney (2016).

Sensitivity tests indicate the importance of controlling for noise. Restricting the sample to the farmout agreements released on days without other relevant (price sensitive) announcements increases considerably the explanatory power of the model, driven mainly by oil price volatility. Additional robustness tests adjusting for robust standard errors clustered by firm and year report similar results to the primary analysis, with the exception of the expertise hypothesis proxied by the presence of unconventional reserves.

In terms of limitations, there is paucity of disclosure for some of the variables that we use. For example, the identification of oil and gas 'majors' in the farmout agreements is restricted due to either the presence of confidentiality provisions or the use of subsidiaries when disclosing the agreements to the market. Further, the lack of an accepted definition of a 'major' and a capital market literature featuring oil and gas 'majors' is a limitation. The fact that daily data for the Fama-French-Cahart model is not available for the Australian market and the presence of small and young oil and gas firms in our sample restrict the use of alternative return benchmarks.

\section{References}

Ball, R., and P. Brown 1968. An empirical evaluation of accounting income numbers. Journal of Accounting Research 6:159-78.

Berg, S. V., and P. Friedman 1977. Joint ventures, competition, and technological complementarities: Evidence from chemicals. Southern Economic Journal 43:1330-7. 
Berkovitch, E., and M. Narayanan 1993. Motives for takeovers: An empirical investigation. Journal of Financial and Quantitative Analysis 28:347-62.

Bertrand, M., and S. Mullainathan 2005. Profitable investments or dissipated cash? Evidence on the investment-cash flow relationship from oil and gas lease bidding. Working Paper, National Bureau of Economic Research.

Beshears, J. 2013. The performance of corporate alliances: Evidence from oil and gas drilling in the Gulf of Mexico. Journal of Financial Economics 110:324-46.

Bodie, Z., and V. I. Rosansky 1980. Risk and return in commodity futures. Financial Analysts Journal 36:27-39.

Brennan, M. J., and E. S. Schwartz 1985. Evaluating natural resource investments. Journal of Business 58:135-57.

Brooke, J., and B. Oliver 2005. The source of abnormal returns from strategic alliance announcements. Pacific-Basin Finance Journal 13:145-61.

Brown, P., A. Ferguson, and K. Stone 2008. Share purchase plans in Australia: Issuer characteristics and valuation implications. Australian Journal of Management 33:307-32.

Chan, S. H., J. W. Kensinger, A. J. Keown, and J. D. Martin 1997. Do strategic alliances create value? Journal of Financial Economics 46:199-221.

Coase, R. H. 1937. The nature of the firm. Economica 4:386-405.

Coase, R. H. 1990. Accounting and the theory of the firm. Journal of Accounting and Economics 12:3-13.

Cortazar, G., and E. S. Schwartz 1997. Implementing a real option model for valuing an undeveloped oil field. International Transactions in Operational Research 4:125-37.

Das, S., P. K. Sen, and S. Sengupta 1998. Impact of strategic alliances on firm valuation. Academy of Management Journal 41:27-41.

Ferguson, A., and P. Lam 2016. Government policy uncertainty and stock prices: The case of Australia's uranium industry. Energy Economics 60:97-111.

Folta, T. B., and K. D. Miller 2002. Real options in equity partnerships. Strategic Management Journal 23:77-88.

Geske, R. 1979. The valuation of compound options. Journal of Financial Economics 7:63-81.

Glambosky, M., K. Gleason, and M. Murdock 2015. Political risk and the factors that affect international bids. Global Finance Journal 28:68-83.

Grullon, G., E. Lyandres, and A. Zhdanov 2012. Real options, volatility, and stock returns. Journal of Finance 67:1499-537.

Hayek, F. A. 1945. The use of knowledge in society. American Economic Review 35:519-30. 
Hendricks, K., and R. H. Porter 1992. Joint bidding in federal OCS auctions. American Economic Review 82:506-11.

Hendricks, K., and R. H. Porter 1996. The timing and incidence of exploratory drilling on offshore wildcat tracts. American Economic Review 86:388-407.

Hendricks, K., R. H. Porter, and B. Boudreau 1987. Information, returns, and bidding behavior in OCS auctions: 1954-1969. Journal of Industrial Economics 35:517-42.

Jensen, M. C., and W. H. Meckling 1995. Specific and general knowledge, and organizational structure. Journal of Applied Corporate Finance 8:4-18.

Johnson, S. A., and M. B. Houston 2000. A reexamination of the motives and gains in joint ventures. Journal of Financial and Quantitative Analysis 35:67-85.

Kent, D. H. 1991. Joint ventures vs. non-joint ventures: An empirical investigation. Strategic Management Journal 12:387-93.

Kogut, B. 1991. Joint ventures and the option to expand and acquire. Management Science 37:19-33.

Koh, J., and N. Venkatraman 1991. Joint venture formations and stock market reactions: An assessment in the information technology sector. Academy of Management Journal 34:869-92.

Leland, H.E., and D. H. Pyle 1977. Informational asymmetries, financial structure, and financial intermediation. Journal of Finance 32:371-87.

Lerner, J., H. Shane, and A. Tsai 2003. Do equity financing cycles matter? Evidence from biotechnology alliances. Journal of Financial Economics 67:411-46.

Lowe, J. S. 1987. Analyzing oil and gas farmout agreements. SW LJ 41:759-868.

McConnell, J., and T. Nantell 1985. Corporate combinations and common stock returns: The case of joint ventures. Journal of Finance 40:519-36.

Mead, W. J. 1967. The competitive significance of joint ventures. Antitrust Bulletin 12:819.

Miloud, T. 2016. The venture capital certification role in initial public offerings. Journal of Applied Business Research. 32:479.

Moel, A., and P. Tufano 2002. When are real options exercised? An empirical study of mine closings. Review of Financial Studies 15:35-64.

Myers, S. C. 1977. Determinants of corporate borrowing. Journal of Financial Economics $5: 147-75$.

Nicholson, S., P. Danzon, and J. McCullough 2005. Biotech-pharmaceutical alliances as a signal of asset and firm quality. Journal of Business 78:1433-64.

Owen, S., and A. Yawson 2015. R\&D intensity, cross-border strategic alliances, and valuation effects. Journal of International Financial Markets Institutions and Money 35:1-17. 
Ozmel, U., D. T. Robinson, and T. E. Stuart 2013. Strategic alliances, venture capital, and exit decisions in early stage high-tech firms. Journal of Financial Economics 107:655-70.

Paddock, J. L., D. R. Siegel, and J. L. Smith 1988. Option valuation of claims on real assets: The case of offshore petroleum leases. Quarterly Journal of Economics 103:479-508.

Palia, D., S. A., Ravid, and N. Reisel 2007. Choosing to cofinance: Analysis of project-specific alliances in the movie industry. Review of Financial Studies 21:483-511.

Robinson, D. T., and T. E. Stuart 2007. Financial contracting in biotech strategic alliances. Journal of Law and Economics 50:559-96.

Rudenno, V. 2012. The mining valuation handbook: Mining and energy valuation for investors and management. John Wiley \& Sons.

Sabet, A. H., and R. Heaney 2016. An event study analysis of oil and gas firm acreage and reserve acquisitions. Energy Economics 57:215-27.

Stein, J. C. 2002. Information production and capital allocation: Decentralized versus hierarchical firms. Journal of Finance 57:1891-921.

Stuart, T. E., H. Hoang, and R. C. Hybels 1999. Interorganizational endorsements and the performance of entrepreneurial ventures. Administrative Science Quarterly 44:315-49.

Sweeny, D. H., P. Cody, S. Lindberg, and M. P. Darden 2013. Fracturing relationships: The impact of risk and risk allocation on unconventional oil and gas projects. Texas Journal of Oil, Gas \& Energy Law 9:289.

Thompson, A.G., 2005. Oil and gas farmin and farmout agreements: Issues and approaches from the farmor's perspective. Australian Mining Petroleum Law Association (AMPLA) Yearbook, 2005.

Tordo, S., B. S. Tracy, and N. Arfaa 2011. National oil companies and value creation. Working Paper No. 218, The World Bank.

Tourinho, O. A. 1979. The valuation of reserves of natural resources: An option pricing approach. Unpublished Ph.D Dissertation, University of California, Berkeley.

Weston, J. F., and S. C. Weaver 2004. Mergers \& Acquisitions, McGraw-Hill Professional.

Zou, C. 2017. Unconventional petroleum geology. Elsevier. 


\section{Figure 1}

Frequency of farmout announcements and the lead average of futures prices for the crude WTI

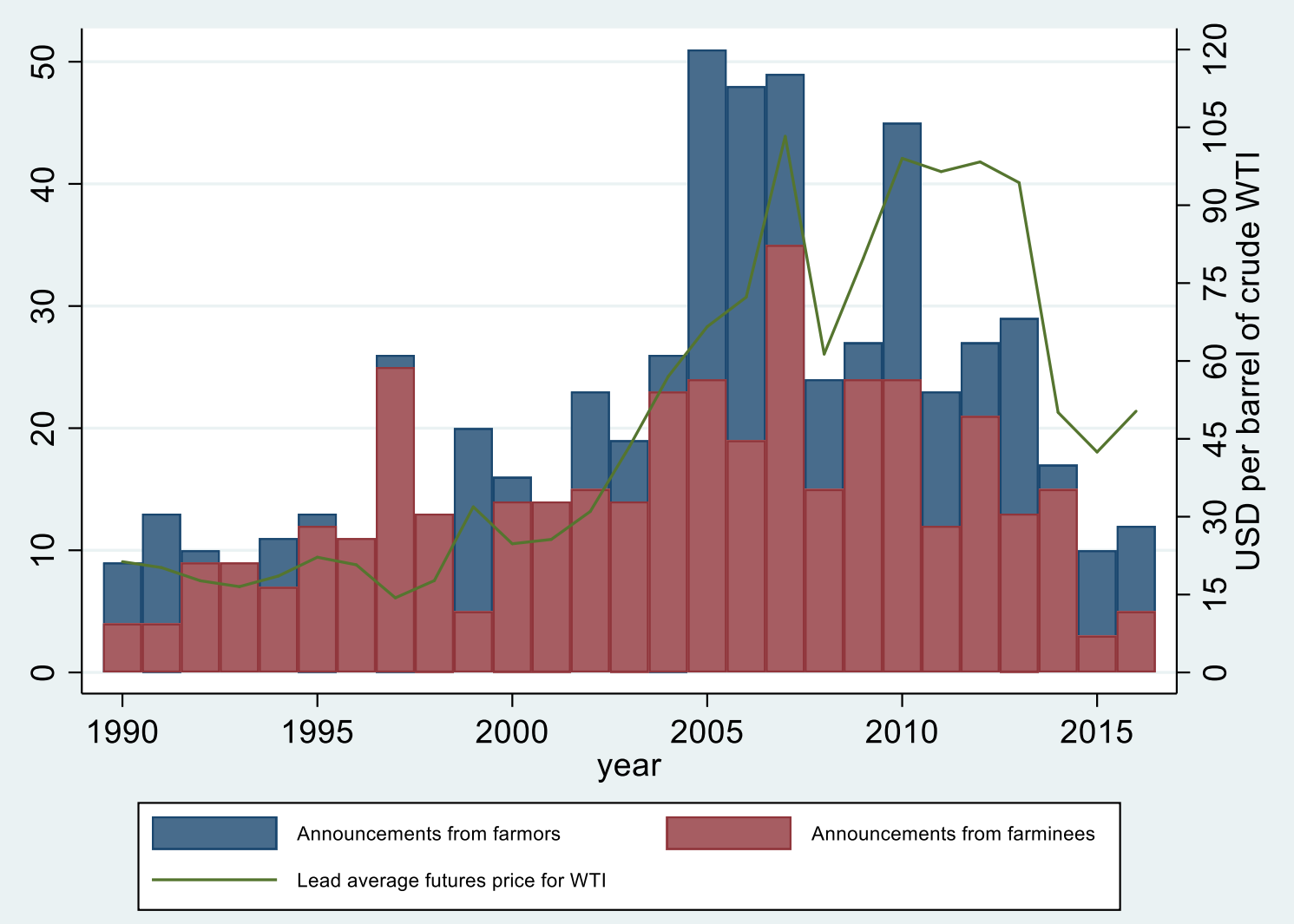

This figure depicts the number of announcements released by farmors and farminees, overlaid with the lead average of futures prices for the crude WTI (West Texas Intermediate). The WTI futures prices are sourced from the US Energy Information Administration (EIA). 
Table 1

Sample selection

\begin{tabular}{|c|c|c|c|}
\hline Description & \multicolumn{2}{|c|}{ Announcements } & Percent \\
\hline Morningstar's Datanalysis Premium: & & 1,820 & $74.3 \%$ \\
\hline Keyword search & 331 & & $13.5 \%$ \\
\hline Content analysis of the announcement headlines & 1,489 & & $60.8 \%$ \\
\hline Add: Factiva & & 582 & $23.8 \%$ \\
\hline Add: Non-energy companies' announcements & & 47 & $1.9 \%$ \\
\hline Equal: Total announcements & & 2,449 & $100.0 \%$ \\
\hline Less: Exclusions & & 1,471 & $60.1 \%$ \\
\hline Subsequent announcements & 1,447 & & $59.1 \%$ \\
\hline Announcements disclosing non-farmin/farmout events & 18 & & $0.7 \%$ \\
\hline Announcements lacking sufficient details & 6 & & $0.2 \%$ \\
\hline Equal: Final sample & & 978 & $39.9 \%$ \\
\hline Announcements by ASX farmor (vendor) firms & 589 & & $24.1 \%$ \\
\hline Announcements by ASX farminee (buyer) firms & 389 & & $15.9 \%$ \\
\hline Less: Agreements announced by two or more ASX firms & & 256 & $10.5 \%$ \\
\hline Equal: Unique farmout agreements & & 722 & $29.5 \%$ \\
\hline
\end{tabular}

This table reports details on the sample selection process. Announcements on farmout agreements are first identified in Morningstar's Datanalysis Premium database for oil and gas firms listed on ASX spanning the period 1990-2016. The sample is then augmented with additional keyword searches on Factiva for the period 1990-2000 confined to constituents of the oil and gas sector listed on ASX. 
Table 2

Announcement frequency over time

\begin{tabular}{|c|c|c|c|c|c|c|c|c|c|}
\hline \multirow[b]{2}{*}{ Year } & \multicolumn{3}{|c|}{$\begin{array}{c}\text { Unique farmout } \\
\text { agreements }\end{array}$} & \multicolumn{3}{|c|}{ Announcements by farmors } & \multicolumn{3}{|c|}{$\begin{array}{c}\text { Announcements by } \\
\text { farminees }\end{array}$} \\
\hline & Freq. & Percent & $\begin{array}{l}\text { Cum. } \\
\text { Percent }\end{array}$ & Freq. & Percent & $\begin{array}{l}\text { Cum. } \\
\text { Percent }\end{array}$ & Freq. & Percent & $\begin{array}{l}\text { Cum. } \\
\text { Percent }\end{array}$ \\
\hline 1990 & 10 & $1 \%$ & $1 \%$ & 9 & $2 \%$ & $2 \%$ & 4 & $1 \%$ & $1 \%$ \\
\hline 1991 & 10 & $1 \%$ & $3 \%$ & 13 & $2 \%$ & $4 \%$ & 4 & $1 \%$ & $2 \%$ \\
\hline 1992 & 14 & $2 \%$ & $5 \%$ & 10 & $2 \%$ & $5 \%$ & 9 & $2 \%$ & $4 \%$ \\
\hline 1993 & 15 & $2 \%$ & $7 \%$ & 9 & $2 \%$ & $7 \%$ & 9 & $2 \%$ & $7 \%$ \\
\hline 1994 & 13 & $2 \%$ & $9 \%$ & 11 & $2 \%$ & $9 \%$ & 7 & $2 \%$ & $8 \%$ \\
\hline 1995 & 19 & $3 \%$ & $11 \%$ & 13 & $2 \%$ & $11 \%$ & 12 & $3 \%$ & $12 \%$ \\
\hline 1996 & 15 & $2 \%$ & $13 \%$ & 9 & $2 \%$ & $13 \%$ & 11 & $3 \%$ & $14 \%$ \\
\hline 1997 & 35 & $5 \%$ & $18 \%$ & 26 & $4 \%$ & $17 \%$ & 25 & $6 \%$ & $21 \%$ \\
\hline 1998 & 19 & $3 \%$ & $21 \%$ & 11 & $2 \%$ & $19 \%$ & 13 & $3 \%$ & $24 \%$ \\
\hline 1999 & 16 & $2 \%$ & $23 \%$ & 20 & $3 \%$ & $22 \%$ & 5 & $1 \%$ & $25 \%$ \\
\hline 2000 & 21 & $3 \%$ & $26 \%$ & 16 & $3 \%$ & $25 \%$ & 14 & $4 \%$ & $29 \%$ \\
\hline 2001 & 15 & $2 \%$ & $28 \%$ & 12 & $2 \%$ & $27 \%$ & 14 & $4 \%$ & $33 \%$ \\
\hline 2002 & 26 & $4 \%$ & $32 \%$ & 23 & $4 \%$ & $31 \%$ & 15 & $4 \%$ & $37 \%$ \\
\hline 2003 & 22 & $3 \%$ & $35 \%$ & 19 & $3 \%$ & $34 \%$ & 14 & $4 \%$ & $40 \%$ \\
\hline 2004 & 31 & $4 \%$ & $39 \%$ & 26 & $4 \%$ & $39 \%$ & 23 & $6 \%$ & $46 \%$ \\
\hline 2005 & 51 & $7 \%$ & $46 \%$ & 51 & $9 \%$ & $47 \%$ & 24 & $6 \%$ & $52 \%$ \\
\hline 2006 & 53 & $7 \%$ & $53 \%$ & 48 & $8 \%$ & $55 \%$ & 19 & $5 \%$ & $57 \%$ \\
\hline 2007 & 60 & $8 \%$ & $62 \%$ & 49 & $8 \%$ & $64 \%$ & 35 & $9 \%$ & $66 \%$ \\
\hline 2008 & 30 & $4 \%$ & $66 \%$ & 24 & $4 \%$ & $68 \%$ & 15 & $4 \%$ & $70 \%$ \\
\hline 2009 & 40 & $6 \%$ & $71 \%$ & 27 & $5 \%$ & $72 \%$ & 24 & $6 \%$ & $76 \%$ \\
\hline 2010 & 54 & $7 \%$ & $79 \%$ & 45 & $8 \%$ & $80 \%$ & 24 & $6 \%$ & $82 \%$ \\
\hline 2011 & 30 & $4 \%$ & $83 \%$ & 23 & $4 \%$ & $84 \%$ & 12 & $3 \%$ & $85 \%$ \\
\hline 2012 & 41 & $6 \%$ & $89 \%$ & 27 & $5 \%$ & $88 \%$ & 21 & $5 \%$ & $91 \%$ \\
\hline 2013 & 34 & $5 \%$ & $93 \%$ & 29 & $5 \%$ & $93 \%$ & 13 & $3 \%$ & $94 \%$ \\
\hline 2014 & 26 & $4 \%$ & $97 \%$ & 17 & $3 \%$ & $96 \%$ & 15 & $4 \%$ & $98 \%$ \\
\hline 2015 & 10 & $1 \%$ & $98 \%$ & 10 & $2 \%$ & $98 \%$ & 3 & $1 \%$ & $99 \%$ \\
\hline 2016 & 12 & $2 \%$ & $100 \%$ & 12 & $2 \%$ & $100 \%$ & 5 & $1 \%$ & $100 \%$ \\
\hline Total & 722 & $100 \%$ & - & 589 & $100 \%$ & - & 389 & $100 \%$ & - \\
\hline
\end{tabular}

This table reports the distribution of farmout agreements for unique deals and related announcements released by the farmors and farminees across the sample period 1990-2016. 
Table 3

Descriptive statistics for firm- and project-level variables

\begin{tabular}{|c|c|c|c|c|c|c|}
\hline \multicolumn{7}{|c|}{ Panel A: Farmors $(N=589)$} \\
\hline Continuous variables: & $N$ & Mean & Median & SD & Min & Max \\
\hline MCAP (\$ million) & 587 & 469.134 & 23.710 & $3,263.303$ & 0.001 & $46,590.850$ \\
\hline FIRMAGE (years) & 588 & 12.6 & 9.1 & 13.3 & 0.1 & 119.8 \\
\hline TOP20 & 588 & 0.4959 & 0.4970 & 0.1904 & 0.1128 & 0.9255 \\
\hline \multicolumn{7}{|c|}{ Panel B: Farminees $(N=389)$} \\
\hline Continuous variables: & $N$ & Mean & Median & SD & Min & Max \\
\hline$M C A P(\$$ million $)$ & 386 & 2076.992 & 29.035 & $10,863.860$ & 0.040 & $143,065.100$ \\
\hline FIRMAGE (years) & 388 & 17.7 & 11.8 & 18.1 & 0.0 & 126.8 \\
\hline TOP20 & 384 & 0.5320 & 0.5142 & 0.1784 & 0.1204 & 0.9255 \\
\hline \multicolumn{7}{|c|}{ Panel C: Projects $(N=722)$} \\
\hline Continuous variables: & $N$ & Mean & Median & SD & Min & Max \\
\hline NFIRMS & 722 & 2.2 & 2.0 & 0.5 & 2.0 & 5.0 \\
\hline CRISK & 702 & 0.8059 & 0.8838 & 0.1573 & 0.1345 & 0.9517 \\
\hline$A C R E A G E$ (acres) & 566 & $2,048,124$ & 489,763 & $10,100,000$ & 160 & $191,000,000$ \\
\hline OILPVOL & 722 & 0.0205 & 0.0191 & 0.0093 & 0.0067 & 0.0771 \\
\hline Indicator variables: & $N$ & Frequency & $\%$ & & & \\
\hline FINCOM & 722 & 318 & 44.0 & & & \\
\hline FIRSTFARM & 722 & 552 & 61.2 & & & \\
\hline FOREIPART & 722 & 377 & 52.2 & & & \\
\hline MAJORPART & 722 & 40 & 5.5 & & & \\
\hline OFFSHORE & 722 & 318 & 44.0 & & & \\
\hline OPERCHANG & 410 & 156 & 38.0 & & & \\
\hline POTENRES & 722 & 327 & 45.3 & & & \\
\hline UNCONV & 722 & 94 & 13.0 & & & \\
\hline PROJLOC & 722 & 325 & 45.0 & & & \\
\hline
\end{tabular}

This table reports descriptive statistics for variables of firms announcing farmout agreements and project-level variables. MCAP is market capitalization in AUD million. FIRMAGE is firm age in years counting from the listing date to the date of farmout announcement. TOP20 is shareholding held by the largest twenty shareholders in the year prior to the farmout announcement. NFIRMS is number of firms participating in a farmout agreement. CRISK is a proxy for the overall political risk in relation to the jurisdiction in which the farmout area is located, measured in the year prior to the announcement date. This measure ranges from zero to one, with a higher measure indicating lower risk. ACREAGE is farmout surface area measured in acres. OILPVOL is the WTI oil price volatility, calculated using daily price changes over the month of the farmout announcement. FINCOM is coded ' 1 ' if the announced agreement discloses financial commitment between the farmout parties. FIRSTFARM is coded ' 1 ' if the oil and gas permits under the agreement are subject to a first farmout agreement over the sample period. FOREIPART is coded ' 1 ' if the agreement involves one or more foreign participants. MAJORPART is a subgroup of FOREIPART and is coded ' 1 ' if any of the foreign participants belongs to the group of oil and gas majors (see list in Appendix 3). OFFSHORE is coded ' 1 ' if the agreement is for oil and gas permits in offshore areas (marine tracts). OPERCHANG is coded ' 1 ' if the announced agreement discloses permit operatorship status. POTENRES is coded ' 1 ' if the announced agreement discloses potential resources targets in the permit area. UNCONV is coded ' 1 ' if the agreement is for targeting unconventional resources. PROJLOC is coded ' 1 ' if the agreement is for overseas permits (not located in Australia). All variables are winsorised at $1 \%$ and $99 \%$, with the exception of NFIRMS and OILPVOL. 
Table 4

Pearson correlation matrix for firm- and project-level variables of deals announced by farmors

\begin{tabular}{|c|c|c|c|c|c|c|c|c|c|c|c|c|c|c|c|c|}
\hline & (1) & (2) & (3) & (4) & (5) & (6) & (7) & (8) & (9) & (10) & (11) & (12) & (13) & (14) & $(15)$ & (16) \\
\hline (1) $L M C A P$ & 1 & & & & & & & & & & & & & & & \\
\hline (2) LFIRMAGE & $0.403^{* * *}$ & 1 & & & & & & & & & & & & & & \\
\hline (3) TOP20 & 0.061 & $-0.190^{* *}$ & 1 & & & & & & & & & & & & & \\
\hline (4) NFIRMS & -0.063 & 0.092 & $0.178^{* *}$ & 1 & & & & & & & & & & & & \\
\hline (5) LACRES & -0.023 & -0.010 & 0.007 & 0.067 & 1 & & & & & & & & & & & \\
\hline (6) $C R I S K$ & -0.004 & -0.102 & -0.049 & -0.109 & $-0.264^{* * *}$ & 1 & & & & & & & & & & \\
\hline (7) OILPVOL & 0.052 & 0.007 & 0.024 & -0.028 & $-0.174^{* *}$ & -0.006 & 1 & & & & & & & & & \\
\hline (8) FINCOM & -0.058 & -0.052 & -0.016 & -0.037 & 0.065 & $-0.195^{* *}$ & -0.089 & 1 & & & & & & & & \\
\hline (9) FIRSTFARM & -0.010 & -0.046 & $0.195^{* *}$ & $0.136^{*}$ & 0.017 & -0.002 & -0.075 & -0.106 & 1 & & & & & & & \\
\hline (10) FOREIPART & 0.092 & 0.030 & 0.017 & $0.143^{*}$ & 0.013 & $-0.330^{* * *}$ & -0.084 & 0.083 & 0.115 & 1 & & & & & & \\
\hline (11) MAJORPART & 0.103 & 0.038 & 0.093 & 0.0471 & $0.198^{* *}$ & -0.110 & -0.045 & 0.022 & 0.072 & $0.224^{* * *}$ & 1 & & & & & \\
\hline (12) OFFSHORE & 0.077 & $0.156^{*}$ & $0.184^{* *}$ & $0.194^{* *}$ & $0.151^{*}$ & $-0.141^{*}$ & -0.039 & -0.066 & 0.059 & $0.218^{* * *}$ & 0.070 & 1 & & & & \\
\hline (13) OPERCHANG & -0.108 & -0.077 & 0.091 & $-0.126^{*}$ & -0.013 & 0.018 & 0.010 & 0.032 & 0.039 & 0.068 & 0.048 & -0.016 & 1 & & & \\
\hline (14) POTENRES & -0.066 & -0.017 & -0.034 & -0.018 & -0.041 & -0.040 & 0.020 & 0.073 & 0.037 & -0.108 & -0.087 & -0.002 & -0.118 & 1 & & \\
\hline (15) UNCONV & -0.034 & -0.098 & 0.011 & $-0.139^{*}$ & 0.001 & $0.201^{* *}$ & 0.013 & $0.189^{* *}$ & 0.007 & $-0.147^{*}$ & -0.036 & $-0.409^{* * *}$ & 0.121 & -0.081 & 1 & \\
\hline (16) PROJLOC & -0.024 & 0.118 & 0.066 & $0.142^{*}$ & 0.025 & $-0.690^{* * *}$ & 0.074 & $0.163^{* *}$ & $0.168^{* *}$ & $0.390^{* * *}$ & 0.082 & $0.177^{* *}$ & -0.055 & 0.062 & $-0.143^{*}$ & 1 \\
\hline
\end{tabular}

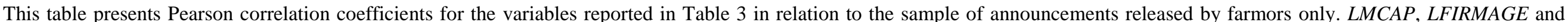

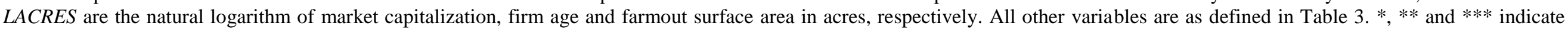
significance at the $10 \%, 5 \%$ and $1 \%$ levels, respectively. 
Table 5 (Panel A)

Average market-adjusted abnormal returns

\begin{tabular}{|c|c|c|c|c|c|c|c|c|c|c|c|c|}
\hline \multirow[b]{2}{*}{$T$} & \multicolumn{5}{|c|}{ Farmors (1) } & \multicolumn{5}{|c|}{ Farminees (2) } & \multicolumn{2}{|c|}{ Difference in means } \\
\hline & $N$ & $A A R$ & $t$-stat & $\begin{array}{c}\text { Count } \\
\text { Positive } \\
A A R\end{array}$ & $\begin{array}{c}\% \\
\text { Positive } \\
A A R\end{array}$ & $N$ & $A A R$ & $t$-stat & $\begin{array}{c}\text { Count } \\
\text { Positive } \\
A A R\end{array}$ & $\begin{array}{c}\% \\
\text { Positive } \\
A A R\end{array}$ & $\begin{array}{c}\text { Diff. } \\
(1)-(2)\end{array}$ & $t$-stat \\
\hline-5 & 493 & 0.0012 & 0.6805 & 238 & $48 \%$ & 306 & 0.0033 & 0.2916 & 154 & $50 \%$ & -0.0020 & -0.5664 \\
\hline-4 & 489 & 0.0026 & 0.9303 & 237 & $48 \%$ & 302 & 0.0010 & 0.1190 & 142 & $47 \%$ & 0.0015 & 0.2798 \\
\hline-3 & 490 & -0.0019 & -0.2596 & 224 & $46 \%$ & 308 & -0.0023 & -1.0914 & 133 & $43 \%$ & 0.0004 & 0.1064 \\
\hline-2 & 485 & 0.0048 & 1.2541 & 247 & $51 \%$ & 299 & 0.0017 & 0.2569 & 145 & $48 \%$ & 0.0031 & 0.8095 \\
\hline-1 & 492 & 0.0063 & $1.9325^{*}$ & 261 & $53 \%$ & 302 & 0.0153 & $3.0051 * * *$ & 162 & $54 \%$ & -0.0089 & $-1.7471^{*}$ \\
\hline 0 & 500 & 0.0251 & $5.3711 * * *$ & 294 & $59 \%$ & 311 & 0.0040 & $1.5820 *$ & 167 & $54 \%$ & 0.0211 & $3.7479 * * *$ \\
\hline 1 & 495 & 0.0041 & 0.9617 & 243 & $49 \%$ & 305 & 0.0005 & 0.1148 & 141 & $46 \%$ & 0.0036 & 0.8699 \\
\hline 2 & 488 & -0.0017 & -0.2521 & 232 & $48 \%$ & 301 & 0.0021 & 1.1141 & 159 & $53 \%$ & -0.0039 & -0.9786 \\
\hline 3 & 489 & -0.0046 & -0.9747 & 214 & $44 \%$ & 298 & -0.0001 & -0.0883 & 151 & $51 \%$ & -0.0046 & -1.1051 \\
\hline 4 & 491 & -0.0059 & -1.4882 & 211 & $43 \%$ & 302 & 0.0028 & 1.2234 & 169 & $56 \%$ & -0.0087 & $-2.1675^{* *}$ \\
\hline 5 & 489 & 0.0034 & 0.9743 & 245 & $50 \%$ & 302 & -0.0010 & -0.3988 & 142 & $47 \%$ & 0.0045 & 1.2041 \\
\hline
\end{tabular}

This table reports the average market-adjusted abnormal returns $(A A R)$ for the farmout agreements announced by farmors and farminees over the 11-day event window centred on the announcement date (day 0). Count positive is the proportion of abnormal returns higher than 0 . The $t$-statistics reported for the abnormal returns follow Kolari and Pynnonen (2010). $t$-statistics for the difference in means are calculated assuming unequal variance. $*, * *$ and $* * *$ indicate significance at the $10 \%, 5 \%$ and $1 \%$ levels, respectively. 
Table 5 (Panel B)

Descriptive statistics for the market-adjusted abnormal returns

\begin{tabular}{|c|c|c|c|c|c|c|c|c|c|c|c|c|}
\hline \multirow[b]{2}{*}{$T$} & \multicolumn{6}{|c|}{ Farmors } & \multicolumn{6}{|c|}{ Farminees } \\
\hline & $N$ & Mean & Median & SD & Min & Max & $N$ & Mean & Median & SD & Min & Max \\
\hline-5 & 493 & 0.0012 & -0.0007 & 0.0543 & -0.3090 & 0.3147 & 306 & 0.0033 & 0.0002 & 0.0463 & -0.2042 & 0.2379 \\
\hline-4 & 489 & 0.0026 & -0.0009 & 0.0538 & -0.2960 & 0.2304 & 302 & 0.0010 & -0.0013 & 0.0862 & -0.3980 & 1.1563 \\
\hline-3 & 490 & -0.0019 & -0.0014 & 0.0517 & -0.2537 & 0.2719 & 308 & -0.0023 & -0.0020 & 0.0512 & -0.1797 & 0.3947 \\
\hline-2 & 485 & 0.0048 & 0.0003 & 0.0505 & -0.2084 & 0.2899 & 299 & 0.0017 & -0.0005 & 0.0540 & -0.5521 & 0.2239 \\
\hline-1 & 492 & 0.0063 & 0.0009 & 0.0575 & -0.3980 & 0.3244 & 302 & 0.0152 & 0.0011 & 0.0763 & -0.1706 & 0.7135 \\
\hline 0 & 500 & 0.0251 & 0.0054 & 0.0840 & -0.3336 & 0.4368 & 311 & 0.0040 & 0.0014 & 0.0742 & -0.6936 & 0.3303 \\
\hline 1 & 495 & 0.0041 & -0.0005 & & -0.2092 & & 305 & & -0.0009 & 0.0516 & -0.2365 & 0.2472 \\
\hline 2 & 488 & -0.0017 & -0.0012 & 0.0567 & -0.2258 & 0.3451 & 301 & 0.0021 & 0.0009 & 0.0525 & -0.1995 & 0.2683 \\
\hline 3 & 489 & -0.0046 & -0.0020 & 0.0565 & -0.2405 & 0.4164 & 298 & -0.0001 & 0.0009 & 0.0561 & -0.3424 & 0.3525 \\
\hline 4 & 491 & -0.0059 & -0.0023 & 0.0709 & -0.9144 & 0.3193 & 302 & 0.0028 & 0.0015 & 0.0423 & -0.1482 & 0.1712 \\
\hline 5 & 489 & 0.0034 & 0.0001 & 0.0591 & -0.1993 & 0.3903 & 302 & -0.0010 & -0.0008 & 0.0444 & -0.2179 & 0.1935 \\
\hline
\end{tabular}

This table reports descriptive statistics of market-adjusted abnormal returns for the farmout agreements announced by farmors and farminees over the 11-day event window centred on the announcement date (day 0). 
Table 6 (Panel A)

Cumulative average market-adjusted abnormal returns

\begin{tabular}{|c|c|c|c|c|c|c|c|c|c|c|c|c|}
\hline \multirow[b]{2}{*}{$\begin{array}{c}\text { Event } \\
\text { window }\end{array}$} & \multicolumn{5}{|c|}{ Farmors (1) } & \multicolumn{5}{|c|}{ Farminees (2) } & \multicolumn{2}{|c|}{ Difference in means } \\
\hline & $\begin{array}{l}\text { No. of } \\
\text { Firms }\end{array}$ & $C A A R$ & $t$-stat & $\begin{array}{c}\text { Count } \\
\text { Positive } \\
C A A R\end{array}$ & $\begin{array}{c}\% \\
\text { Positive } \\
C A A R\end{array}$ & $\begin{array}{l}\text { No. of } \\
\text { Firms }\end{array}$ & $C A A R$ & $t$-stat & $\begin{array}{c}\text { Count } \\
\text { Positive } \\
C A A R\end{array}$ & $\begin{array}{c}\% \\
\text { Positive } \\
C A A R\end{array}$ & $\begin{array}{l}\text { Diff. } \\
(1)-(2)\end{array}$ & $t$-stat \\
\hline$[-1,0]$ & 485 & 0.0318 & $5.5095 * * *$ & 293 & $60 \%$ & 299 & 0.0193 & $3.2454 * * *$ & 173 & $58 \%$ & 0.0125 & $1.9182 *$ \\
\hline$[-1,1]$ & 480 & 0.0360 & $5.4829 * * *$ & 292 & $61 \%$ & 293 & 0.0190 & $3.1261 * * *$ & 159 & $54 \%$ & 0.0170 & $2.3351 * *$ \\
\hline
\end{tabular}

This table reports the cumulative average of the market-adjusted abnormal returns $(C A A R)$ for the farmout agreements announced by farmors and farminees based on three event windows centred on the announcement date (day 0). Count positive is the proportion of abnormal returns higher than 0 . The $t$-statistics reported for the cumulative average abnormal returns follow Kolari and Pynnonen (2010). $t$-statistics for the difference in means are calculated assuming unequal variance. $*, * *$ and $* * *$ indicate significance at the $10 \%, 5 \%$ and $1 \%$ levels, respectively.

Table 6 (Panel B)

Descriptive statistics for the cumulative market-adjusted abnormal returns

\begin{tabular}{cccccccccccccccc}
\hline \multirow{2}{*}{$\begin{array}{c}\text { Event } \\
\text { window }\end{array}$} & $N$ & Mean & Median & SD & Min & Max & & $N$ & Mean & Median & SD & Min & Max \\
\hline$[0,1]$ & 487 & 0.0291 & 0.0100 & 0.0996 & -0.2517 & 0.5097 & & 296 & 0.0049 & 0.0001 & 0.0845 & -0.6797 & 0.3370 \\
{$[-1,0]$} & 485 & 0.0318 & 0.0101 & 0.0954 & -0.2713 & 0.6218 & & 299 & 0.0193 & 0.0060 & 0.0840 & -0.2310 & 0.5530 \\
{$[-1,1]$} & 480 & 0.0360 & 0.0167 & 0.1075 & -0.2349 & 0.5121 & & 293 & 0.0190 & 0.0027 & 0.0925 & -0.2212 & 0.5470 \\
\hline
\end{tabular}

This table presents the descriptive statistics for the cumulative market-adjusted abnormal returns for the farmout agreements announced

by farmors and farminees based on three event windows centred on the announcement date (day 0 ). 
Table 7

Cross-sectional regressions

\begin{tabular}{|c|c|c|c|c|c|c|}
\hline \multirow[b]{2}{*}{ VARIABLES } & \multicolumn{6}{|c|}{ Dependent variable $=C A R[-1,1]$} \\
\hline & $(1)$ & $(2)$ & $(3)$ & $(4)$ & $(5)$ & (6) \\
\hline FINCOM & $0.028 * * *$ & & & $0.028 * * *$ & $0.030 * * *$ & $0.036 * * *$ \\
\hline & $(0.01)$ & & & $(0.01)$ & $(0.01)$ & $(0.01)$ \\
\hline POTENRES & & $\begin{array}{c}0.020 * * \\
(0.01)\end{array}$ & & & & \\
\hline LACRES & & & $\begin{array}{c}0.007 * * \\
(0.00)\end{array}$ & & & \\
\hline FOREIPART & 0.005 & 0.007 & 0.009 & & 0.006 & -0.005 \\
\hline & $(0.01)$ & $(0.01)$ & $(0.01)$ & & $(0.01)$ & $(0.01)$ \\
\hline MAJORPART & & & & $\begin{array}{l}0.004 \\
(0.02)\end{array}$ & & \\
\hline UNCONV & $\begin{array}{c}0.026 * \\
(0.01)\end{array}$ & $\begin{array}{c}0.034 * * \\
(0.01)\end{array}$ & $\begin{array}{l}0.008 \\
(0.02)\end{array}$ & $\begin{array}{c}0.026^{*} \\
(0.01)\end{array}$ & & \\
\hline OFFSHORE & & & & & $\begin{array}{c}-0.009 \\
(0.01)\end{array}$ & \\
\hline OPERCHANG & & & & & & $\begin{array}{l}0.014 \\
(0.01)\end{array}$ \\
\hline OILPVOL & $\begin{array}{c}1.856^{* * * *} \\
(0.53)\end{array}$ & $\begin{array}{c}1.782 * * * \\
(0.53)\end{array}$ & $\begin{array}{c}2.358^{* * *} * \\
(0.59)\end{array}$ & $\begin{array}{c}1.863 * * * \\
(0.53)\end{array}$ & $\begin{array}{c}1.841^{* * *} * \\
(0.53)\end{array}$ & $\begin{array}{l}0.742 \\
(0.66)\end{array}$ \\
\hline$L M C A P$ & $\begin{array}{c}-0.006 * * \\
(0.00)\end{array}$ & $\begin{array}{c}-0.007 * * \\
(0.00)\end{array}$ & $\begin{array}{c}-0.010^{* * * *} \\
(0.00)\end{array}$ & $\begin{array}{c}-0.006^{* *} \\
(0.00)\end{array}$ & $\begin{array}{c}-0.006^{* * *} \\
(0.00)\end{array}$ & $\begin{array}{c}-0.008^{* *} \\
(0.00)\end{array}$ \\
\hline TOP20 & $\begin{array}{c}-0.020 \\
(0.03)\end{array}$ & $\begin{array}{c}-0.016 \\
(0.03)\end{array}$ & $\begin{array}{l}0.011 \\
(0.03)\end{array}$ & $\begin{array}{c}-0.020 \\
(0.03)\end{array}$ & $\begin{array}{c}-0.016 \\
(0.03)\end{array}$ & $\begin{array}{c}-0.025 \\
(0.03)\end{array}$ \\
\hline FIRSTFARM & $\begin{array}{c}-0.006 \\
(0.01)\end{array}$ & $\begin{array}{c}-0.008 \\
(0.01)\end{array}$ & $\begin{array}{c}-0.006 \\
(0.01)\end{array}$ & $\begin{array}{c}-0.006 \\
(0.01)\end{array}$ & $\begin{array}{c}-0.006 \\
(0.01)\end{array}$ & $\begin{array}{c}-0.001 \\
(0.01)\end{array}$ \\
\hline CRISK & $\begin{array}{c}-0.004 \\
(0.04)\end{array}$ & $\begin{array}{r}-0.027 \\
(0.04)\end{array}$ & $\begin{array}{l}0.025 \\
(0.04)\end{array}$ & $\begin{array}{c}-0.009 \\
(0.04)\end{array}$ & $\begin{array}{l}0.001 \\
(0.04)\end{array}$ & $\begin{array}{l}0.011 \\
(0.04)\end{array}$ \\
\hline NFIRMS & $\begin{array}{c}-0.011 \\
(0.01)\end{array}$ & $\begin{array}{c}-0.013 \\
(0.01)\end{array}$ & $\begin{array}{c}-0.016 \\
(0.01)\end{array}$ & $\begin{array}{c}-0.011 \\
(0.01)\end{array}$ & $\begin{array}{r}-0.012 \\
(0.01)\end{array}$ & $\begin{array}{c}-0.008 \\
(0.01)\end{array}$ \\
\hline LFIRMAGE & $\begin{array}{c}0.011 * * \\
(0.00)\end{array}$ & $\begin{array}{c}0.010^{* * *} \\
(0.00)\end{array}$ & $\begin{array}{c}0.013 * * \\
(0.01)\end{array}$ & $\begin{array}{c}0.011^{* *} \\
(0.00)\end{array}$ & $\begin{array}{c}0.011 * * \\
(0.00)\end{array}$ & $\begin{array}{l}0.011^{*} \\
(0.01)\end{array}$ \\
\hline CONSTANT & $\begin{array}{l}0.023 \\
(0.05)\end{array}$ & $\begin{array}{l}0.050 \\
(0.04)\end{array}$ & $\begin{array}{c}-0.080 \\
(0.07)\end{array}$ & $\begin{array}{l}0.027 \\
(0.04)\end{array}$ & $\begin{array}{l}0.024 \\
(0.05)\end{array}$ & $\begin{array}{l}0.027 \\
(0.06)\end{array}$ \\
\hline Observations & 463 & 463 & 349 & 463 & 463 & 274 \\
\hline Adjusted $R$-sq. & 0.059 & 0.052 & 0.061 & 0.059 & 0.054 & 0.041 \\
\hline$F$-statistic & 3.91 & 3.55 & 3.26 & 3.89 & 3.62 & 2.18 \\
\hline Prob. $>F$-Stat & 0.000 & 0.000 & 0.000 & 0.000 & 0.000 & 0.020 \\
\hline
\end{tabular}

This table presents the estimated coefficients from the regression of the three-day cumulative marketadjusted abnormal return $C A R[-1,1]$ for the farmout agreements released by farmors. Column (1) reports results for the base model (Equation 3) for testing the main hypotheses: pooling of resources is tested through FINCOM, certification is tested through FOREIPART, expertise and knowledge is tested through UNCONV and real options theory is tested through OILPVOL. The results for alternative proxies for these hypotheses are shown in Columns (2)-(6). See Table 3 for definitions of the variables used. All continuous variables are winsorised at $1 \%$ and $99 \%$, except NFIRMS and OILPVOL. Standard errors are in parentheses. *, ** and *** indicate significance at the $10 \%, 5 \%$ and $1 \%$ levels, respectively. 
Table 8

Sensitivity analysis controlling for confounding announcements

\begin{tabular}{|c|c|c|c|}
\hline \multirow[b]{2}{*}{ VARIABLES } & \multicolumn{3}{|c|}{ Dependent variable $=C A R[-1,1]$} \\
\hline & $(1)$ & $(2)$ & (3) \\
\hline \multirow[t]{2}{*}{ FINCOM } & $0.034 * * *$ & $0.033 * *$ & $0.028 * *$ \\
\hline & $(0.01)$ & $(0.01)$ & $(0.01)$ \\
\hline \multirow[t]{2}{*}{ FOREIPART } & 0.010 & -0.004 & 0.007 \\
\hline & $(0.01)$ & $(0.02)$ & $(0.01)$ \\
\hline \multirow{2}{*}{ UNCONV } & 0.026 & -0.002 & 0.023 \\
\hline & $(0.02)$ & $(0.02)$ & $(0.02)$ \\
\hline \multirow[t]{2}{*}{ OILPVOL } & $3.260 * * *$ & $3.277 * * *$ & $2.624 * * *$ \\
\hline & $(0.67)$ & $(0.81)$ & $(0.63)$ \\
\hline \multirow[t]{2}{*}{ LMCAP } & $-0.010 * *$ & $-0.009 *$ & $-0.009 * *$ \\
\hline & $(0.00)$ & $(0.00)$ & $(0.00)$ \\
\hline \multirow[t]{2}{*}{ TOP2O } & 0.038 & 0.047 & 0.018 \\
\hline & $(0.04)$ & $(0.04)$ & $(0.04)$ \\
\hline \multirow[t]{2}{*}{ FIRSTFARM } & -0.009 & -0.013 & -0.007 \\
\hline & $(0.01)$ & $(0.01)$ & $(0.01)$ \\
\hline \multirow[t]{2}{*}{ CRISK } & 0.022 & 0.015 & 0.011 \\
\hline & $(0.05)$ & $(0.06)$ & $(0.04)$ \\
\hline \multirow[t]{2}{*}{ NFIRMS } & -0.010 & -0.002 & -0.010 \\
\hline & $(0.01)$ & $(0.01)$ & $(0.01)$ \\
\hline \multirow[t]{2}{*}{ LFIRMAGE } & $0.019 * * *$ & $0.021 * * *$ & $0.016 * * *$ \\
\hline & $(0.01)$ & $(0.01)$ & $(0.01)$ \\
\hline \multirow[t]{2}{*}{ CONFOUN3DAY } & & & 0.004 \\
\hline & & & $(0.01)$ \\
\hline \multirow[t]{2}{*}{ CONSTANT } & -0.064 & -0.074 & -0.030 \\
\hline & $(0.06)$ & $(0.07)$ & $(0.06)$ \\
\hline Observations & 329 & 232 & 382 \\
\hline Adjusted $R$-sq. & 0.133 & 0.126 & 0.094 \\
\hline$F$-statistic & 4.87 & 3.18 & 3.48 \\
\hline Prob. $>F$-stat & 0.000 & 0.001 & 0.000 \\
\hline
\end{tabular}

This table presents the estimated coefficients from the regression of the three-day cumulative market-adjusted abnormal return $C A R[-1,1]$ for the farmout agreements released by farmors, controlling for confounding announcements. Column (1) reports results for the base model (Equation 3) based on a restricted sample after excluding 134 farmout agreements announced on days with other market sensitive announcement. Column (2) reports results for the base model based on a restricted sample after excluding 231 farmout agreements with contemporaneous market sensitive announcement released over a 3-day event window centred on the event date. Column (3) reports results for the base model with the inclusion of a control (CONFOUN3DAY) for the count of market sensitive announcements released by farmor over the three-day event window centred on the event date. See Table 3 for definitions of the variables used. All continuous variables are also winsorised at $1 \%$ and $99 \%$ except NFIRMS and OILPVOL. Standard errors are reported in parentheses. *, ** and *** indicate significance at the $10 \%, 5 \%$ and $1 \%$ levels, respectively. 


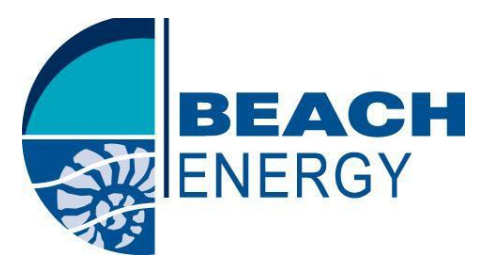

For Immediate Release - 25 February 2013 Ref. \#007/13

ASX Ltd/SGX Singapore Exchange Ltd Companies Announcement Office Electronic Lodgement System

\section{ASX Release}

Beach Energy Ltd

ABN: 20007617969

ASX Code: BPT

25 Conyngham Street

GLENSIDE SA 5065

GPO Box 175

ADELAIDE SA 5001

Tel: +61883382833

Fax: +61883382336

Web:

www.beachenergy.com.au

Email:

info@beachenergy.com.au

Dear Sir,

\section{BEACH FARM-OUT OF EXPLORATION ACREAGE IN NAPPAMERRI TROUGH TO CHEVRON}

Beach will transfer up to $60 \%$ of its interests in PEL 218 (Beach 100\%) and ATP 855 (Beach $60 \%$ ) to Chevron. It is envisaged that Beach will potentially receive US\$349 million over two stages for both permits over several years.

Beach Energy Limited (ASX: BPT, "Beach") and Beach group subsidiaries, have signed documents with Chevron Australia Exploration 1 Pty Ltd and Chevron Australia Holdings Pty Ltd ("Chevron") to farm-out a portion of their interests in the PEL 218 (South Australia) and ATP 855 (Queensland) joint ventures.

Completion of the transaction is conditional upon:

- all relevant government approvals, including FIRB approval;

- approval and registration of the farm-in agreement in relation to PEL 218 by government authorities in South Australia;

- indicative approval of the transfers of interests in ATP 855 to Chevron by government authorities in Queensland; and

- approval and registration of the transfers of the interests by relevant authorities for each stage.

Icon Energy Ltd (ASX: ICN, “Icon"), Beach's joint venture partner in ATP 855, has consented to and waived its pre-emptive rights in relation to each stage of the transaction.

Subject to joint venture approvals, the key work program elements envisaged across the two permits involve an intial exploration program to be followed by pilot production programs.

The financial commitment by Chevron to Beach is detailed in the table below:

\section{PEL 218}

\section{Stage 1}

Acquire an initial equity interest of $30 \%$ through:

- US\$36 million cash

- US $\$ 95$ million carry

\section{ATP 855}

Acquire an initial equity interest of $18 \%$ through:

- US\$59 million cash 


\begin{tabular}{|c|c|c|}
\hline & $\begin{array}{l}\text { On completion of Stage } 1 \text { work program, } \\
\text { Chevron election to proceed to Stage } 2\end{array}$ & $\begin{array}{l}\text { Chevron election to proceed to acquire } \\
\text { Stage } 2 \text { in the period from } 1 \text { September } \\
2014 \text { to } 31 \text { March } 2015\end{array}$ \\
\hline Stage 2 & $\begin{array}{l}\text { Acquire an additional } 30 \% \text { interest } \\
\text { through: } \\
\text { - US } \$ 41 \text { million cash } \\
\text { - US } \$ 47 \text { million carry } \\
\text { On completion of Stage } 2 \text { work program, } \\
\text { Chevron election to proceed }\end{array}$ & $\begin{array}{l}\text { Acquire an additional } 18 \% \text { interest } \\
\text { through: } \\
\text { - US } \$ 36 \text { million cash } \\
\text { Chevron election, from } 1 \text { October } 2016 \text { to } \\
31 \text { December } 2016 \text {, to proceed }\end{array}$ \\
\hline Post $S$ & $\begin{array}{l}\text { Commitment bonus payment of } \\
\text { US } \$ 35 \text { million }\end{array}$ & \\
\hline
\end{tabular}

Note 1: Stage 1 has already commenced and includes wells after Encounter-1 and Holdfast-1 for PEL 218 Note 2: Timing of the stages for PEL 218 are expected to be in line with that of ATP 855

If after Stage 1, Chevron elects not to proceed to acquire Stage 2, the interest held by Chevron will be re-assigned to Beach for no consideration. If after Stage 2, Chevron elects not to proceed, Beach may elect to receive a re-assignment of the interests held by Chevron.

As a result of this farm-out to Chevron, Beach is well positioned for long-term appraisal and development of the Nappamerri Trough gas resources. Post Stage 2, Beach will support Chevron should it nominate for operatorship.

Beach has led the way in unconventional exploration of the Nappamerri Trough in both South Australia and Queensland. Beach's identification of this shale and basin centred gas opportunity in the Cooper Basin resulted in Beach taking an early landholding position in both PEL 218 and ATP 855, with six vertical wells in PEL 218 and one in ATP 855 drilled to date.

Beach's Managing Director, Reg Nelson, said: "This transaction vindicates in many ways the vision that the company has in relation to the potential of unconventional gas in the Cooper Basin. We look forward to working closely with Chevron and Icon Energy in the continued rejuvenation of the Cooper Basin."

\section{Icon put option}

A put option has been granted by Beach to Icon, exercisable by Icon up to 30 June 2013, for Beach to acquire $4.9 \%$ of ATP 855 from Icon on payment by Beach of US $\$ 18$ million.

Yours sincerely,

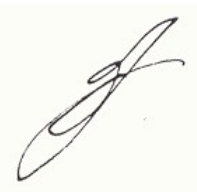

\section{Reg Nelson}

Managing Director, FAusIMM 


\section{Appendix 2}

Example of a farmout agreement timeline

\begin{tabular}{|c|c|c|c|c|c|}
\hline Announcement & Date & Headline & Project & Content summary & Comments \\
\hline $1^{\text {st }}$ & $20 / 07 / 2009 *$ & $\begin{array}{l}\text { New Guinea Energy } \\
\text { Ltd signs Heads of } \\
\text { Agreement }\end{array}$ & $\begin{array}{l}\text { PPLs267, } 268 \\
\text { and } 269\end{array}$ & $\begin{array}{l}\text { - heads of agreement with a major multinational partner to fund } \\
\text { seismic programs and well drilling; } \\
\text { - partner funds up to US } \$ 15 \text { million for each well in exchange of } \\
\text { permit's interest. }\end{array}$ & $\begin{array}{l}\text { first farmout } \\
\text { announcement between } \\
\text { New Guinea Energy Ltd } \\
\text { (farmor) and an unknown } \\
\text { multinational partner } \\
\text { (farminee). }\end{array}$ \\
\hline $2^{\text {nd }}$ & $01 / 09 / 2009$ & $\begin{array}{l}\text { Update on Heads of } \\
\text { Agreement }\end{array}$ & $\begin{array}{l}\text { PPLs267, } 268 \\
\text { and } 269\end{array}$ & $\begin{array}{l}\text { - progress of definitive documents which shall be finalised by } \\
15 / 09 / 2009 \text {. }\end{array}$ & $\begin{array}{l}\text { subsequent farmout } \\
\text { update. }\end{array}$ \\
\hline $3^{\text {rd }}$ & $15 / 09 / 2009$ & $\begin{array}{l}\text { Update on Heads of } \\
\text { Agreement }\end{array}$ & $\begin{array}{l}\text { PPLs267, } 268 \\
\text { and } 269\end{array}$ & - three-day deadline extension to finalise the documents. & idem \\
\hline $4^{\text {th }}$ & $18 / 09 / 2009$ & $\begin{array}{l}\text { Binding Farm-In } \\
\text { Agreements Finalised }\end{array}$ & $\begin{array}{l}\text { PPLs267, } 268 \\
\text { and } 269\end{array}$ & $\begin{array}{l}\text { - partner identity revealed: Talisman Energy Inc.; } \\
\text { - farminee agrees upon a total expenditure up to US\$55 million in } \\
\text { exchange of a maximum } 70 \% \text { interest in PPL } 269 ; \\
\text { - farminee is also to fund up to up to US\$50 million in exchange of } \\
\text { a maximum } 70 \% \text { interest in PPL } 268 \text {. }\end{array}$ & $\begin{array}{l}\text { farmout agreement } \\
\text { conclusion. }\end{array}$ \\
\hline $5^{\text {th }}$ & 09/10/2009 & $\begin{array}{l}\text { Variation Approvals } \\
\text { for PPLs } 268 \text { and } 269\end{array}$ & $\begin{array}{l}\text { PPLs } 268 \text { and } \\
269\end{array}$ & $\begin{array}{l}\text { - approval from the government of Papua New Guinea to undertake } \\
\text { the exploration project. }\end{array}$ & $\begin{array}{l}\text { formal government } \\
\text { approval. }\end{array}$ \\
\hline
\end{tabular}

\footnotetext{
* Although the document is signed on 17 July, it is publicly available on 20 July, which is the ASX announcing date in terms of market disclosure.
} 


\section{Appendix 3}

List of major oil and gas companies

\begin{tabular}{cllc}
\hline Rank & Major & Country & Sales (USD billion) \\
\hline 1 & Royal Dutch Shell Group & Netherlands & 261.7 \\
2 & China Petroleum \& Chemical Corp. & China & 256.1 \\
3 & PetroChina Co. Ltd. & China & 215.4 \\
4 & BP Plc & United Kingdom & 205.0 \\
5 & Exxon Mobil Corp. & United States & 197.5 \\
6 & Total SA & France & 124.6 \\
7 & Chevron Corp. & United States & 110.5 \\
8 & Gazprom PJSC & Russia & 92.3 \\
9 & Petrobras Petróleo Brasileiro SA & Brazil & 74.4 \\
10 & Eni SpA & Italy & 60.0 \\
11 & JXTG Holdings & Japan & 57.0 \\
12 & Statoil ASA & Norway & 44.3 \\
13 & Repsol SA & Spain & 37.3 \\
\hline
\end{tabular}

This list of oil and gas 'majors' is constructed as follows. First, a ranking of the twenty largest energy companies based on total sales is obtained (based on the total sales in 2016 from Factiva's peer comparison). Subsequently, the list of 20 companies is modified based on: (i) company's primary industry classification to capture companies operating mainly in the upstream sector (Crude Oil/Natural Gas Upstream Operations, SIC code 1311, or Oil and Gas Field Exploration Services, SIC code 1382), (ii) segment reporting showing the upstream segment's sales, and (iii) the presence of at least one overseas project. 